\title{
Text-Image Relations in Print Advertisement: A Multimodal Discourse Analysis
}

\author{
Yasmin M. El-Sayed \\ Banha University
}

\begin{abstract}
The present paper focuses on the semantic relations that hold between the text and image in advertisement. Advertisement is a discourse genre in which both textual and visual modes are employed for attaining communicative goals. The paper investigates text-image relations in commercial and noncommercial advertisements.

Drawing upon the recently developed field of multimodal discourse analysis, within Hallidayan Systemic Functional Linguistics, particularly Martinec \& Salway's system, the paper examines the integration of the textual and visual modes and the ways they contribute to the meaning-making process in the genre.

Key words: multimodality, multimodal discourse analysis, advertisement, text-image relations.
\end{abstract}


Text-Image Relations in Print Advertisement: A Multimodal Discourse Analysis

Text-Image Relations in Print Advertisement: A

Multimodal Discourse Analysis

\author{
Yasmin M. El-Sayed \\ Banha University
}

\title{
1- Introduction:
}

Language is the primary tool for the communication of meaning in discourse. Two basic modes are employed, namely, writing and speech. However, the advance in new technology has introduced new modes for representing meaning such as the use of digital photography. Language and other modes like image take part in communication, which is now known as Multimodal Communication. According to the National Centre for Research Methods (NCRM) (2012), multimodal communication is the relation that holds between all modes used in communication and the way they are represented.

Print advertisement is an instance of the variety of roles that discourse can perform in society. It is an instance of how "people communicate and relate to each other within the different spheres where they perform their daily activities." (Simoes \& Freitas, 2012, p.427). Advertising has existed since the nineteenth century. However, the advance in advertising has accompanied the social and technological evolution. Diverse modes are employed which not only include language but also visual images such as pictures, photos, graphics or cartoons. The present study is an attempt to investigate the text-image relations in print advertisements as a model of multimodal text.

\section{2- Objectives of the study:}

The following objectives are attempted in the present study:

1) To investigate the verbal and visual modes that form the structure of advertisements: to explore their relations semantically and the way they interact.

\section{ELLS Vol.9 No.I (544) SPU December 2018}


2) To broaden the understanding of the functional reasons behind the employment of both modes. This is achieved through both examining language usage and linguistic implication and identifying image decisions that are made by marketing and design experts.

3) To broaden the understanding of how advertising works in society.

More specifically, the study aims to find answers to the following questions:

1) Why are both the image and the text employed in the advertisement?

2) How are they utilized to achieve the advertiser's goals?

3) What are the differences between commercial and noncommercial advertisements as a multimodal text?

4) Are there differences between Arabic and English advertisements due to difference in language/culture?

\section{3- Methodology:}

The study adopts a descriptive-qualitative analysis method to investigate print advertisements that feature both verbal language and visual image. The analysis follows the following steps:

1) It begins with identifying the context of the advertisement.

2) The visual and verbal elements of the advertisement are assigned based on the Generic Structure Potential of a Print Advertisement (GSP) proposed by Cheong (2004).

3) The verbal text is segmented into units of analysis. The minimal unit of analysis is the clause. However, it could be larger; the largest is the paragraph.

4) Each verbal unit of analysis and its related visual element are analyzed in terms of status and logico-semantic relations based on Martinec \& Salway's (2005) system of text-image relations.

\section{4- Data of analysis:}

The data consist of eight print magazine advertisements that are randomly selected. Four are in English and four are in Arabic. The ads promote material products and goods like shampoo and VCR.

\section{ELLS Vol.9 No.I (545) SPU December 2018}


Text-Image Relations in Print Advertisement: A Multimodal Discourse Analysis

Others promote the idea of donation for human causes like charities. Both modes, the written language and the image, are present in each ad.

\section{5- Background:}

\section{5-1- Multimodal Discourse Analysis (MDA): An Overview}

In the multimodal approach to discourse, language is regarded as one of the modes that are available for representation of meaning. MDA indicates that "different semiotic modes... are combined and integrated in a given instance of discourse" (van Leeuwen, 2015, p. 447). According to MDA, the study of language extends to "the study of language in combination with other resources, such as images, scientific symbolism, gesture, action, music, and sound" (O'Halloran, 2011, p.120). It "needs to encompass all modes used in any text or text-like entity, with each described both in terms specific to its material... and in terms shared by all modes" (Kress, 2012, p.38). In other words, MDA focuses on both the characteristic features and mutual relations between the employed modes. A mode is defined as "a socially shaped and culturally given resource for making meaning" (Kress, 2009, p. 54). Cultural, historical, and social uses of the modes play an essential role in their form and shape.

The growing interest in MDA is supported by several reasons: first, the inherent belief that all discourse is multimodal. Originally, diverse modes, in addition to language, are employed to convey meaning such as intonation in spoken language. Second, the emergence of new forms of discourse and the increasing multimodal nature of contemporary communication and technology allowed for the combination of texts and images within certain layouts. A trend has been observed towards the visual representation of information which was formerly language-dependent. Third, "technologies to develop new methodological approaches for MDA, for example, multimodal annotation tools, have become available and affordable" (O'Halloran, 2011, p. 122).

\section{$\begin{array}{llllll}\text { ELLS Vol.9 No.I } & \text { (546) SPU December } 2018\end{array}$}




\section{5-1-1- MDA Origins \& Central Concepts:}

The shaping of multimodality took subsequent stages, each affecting the concept in a certain way. The interest in multimodality can be dated back to the 1930s and 1940s Prague school. Linguistics is employed to investigate new aspects of language such as visual art and the nonverbal aspect of the theatre (Veltrusky 1946).

Paris Structuralist School in the 1960s applied linguistic concepts to get a better understanding of popular culture and mass media. Barthes (1967, 1977, and 1983) is a major influence. In his work on fashion and visual images, he distinguished between the denotative and connotative meanings of components of a photograph such as the people, the places and so forth. Barthes, in his work on text-image relations, distinguished THREE relations: anchor, illustration, and relay.

Around the same time period, American linguists paid attention to MDA of spoken language and nonverbal communication such as the analysis of the first five minutes of a psychiatric interview as an instance of spoken discourse (Pittenger, Hockett, and Danley 1960).

The Sydney School of Semiotics (Social Semiotics) is inspired by M.A.K. Halliday (1978) as he developed the social semiotic approach to language and communication in his Systemic Functional theory of Linguistics:

Social semiotic analysis of multimodal texts is based on M.A.K. Halliday's (1978) theory of 'metafunctions' [ideational, interpersonal, and textual] to identify three distinct but coexisting kinds of meaning that interplay within any text... Systemic Functional theory provides a social semiotic framework for the analysis of multimodal texts with context-dependent meaning studies and a comprehensive approach to language. (Wu, 2014, p.1415)

\section{ELLS Vol.9 No.I (547) SPU December 2018}


Text-Image Relations in Print Advertisement: A Multimodal Discourse Analysis

In other words, text and context are interrelated and together they assist language users to convey meanings. In MDA, language is not the primary mode of meaning-making in communication. Rather, it is a part of a multimodal ensemble. Language itself is regarded as composed of TWO distinct modes, namely, speech and writing.

\section{5-2- Advertisement}

Advertisement refers to a form of discourse; an act of communication. Basically, the word 'advertisement' is derived from the Latin root verb 'advertere', which means 'to turn towards'. This implies that one of the main goals of advertisement is to draw audience's attention, whether towards a product or an idea. Besides, advertisement involves a conscious intention, "with the aim of benefiting the originator materially or through some other less tangible gain, such as enhancement of status or image." (Goddard, 1998, p.7). Advertising aims mainly to raise the level of product sales or to promote an idea or service. Thus, the advertisers and marketers employ tools to increase the persuasive appeal and hold the audience's attention.

As an act of communication, three basic elements compose advertisements, namely, the addresser (sender), the message, and the addressee (receiver). The addresser is the actual artist and advertising copywriter who works at an advertising agency. Addressees are the readers who "have to decode the message and understand different address relationships." (Goddard, 1998, p. 10). "These people might be specifically addressed..., or they might be a much less specific group, defined less by explicit name and more by the qualities and values they are thought to possess." (Ibid., p. 31).

There are two types of addressees: the addressees and the 'real' addressees. The former group is not specific; it includes all kinds of people. The real situation is that not all of them would be affected by what is described and shown in the advertisement, nor would they be persuaded by the represented causes. The real addressees, on the other, are readers who read the advertisement and possibly interact with it.

\section{ELLS Vol.9 No.I (548) SPU December 2018}


As for the advertisement message, "the whole aim of the copywriters is to get us to register their communication, either for purposes of immediate action or to make us more favorably disposed in general terms to the advertised product or service." (Ibid., p.11).

As advertisements attempt hard to capture the audience's attention and encourage them to start the decoding process, multimodal texts have been employed where attention-seeking devices assist in achieving the advertisers' goals. Imagery and text are utilized to generate an impact. The combination of both modes is governed by the advertisers' motifs. "Just as the way an image is present can suggest certain ideas..., so the verbal language can suggest particular qualities as a result of how it appears: in other words, writing is a form of image-making too." (Ibid., p. 16).

\section{6- Theoretical Framework:}

The present study draws on a combined framework of TWO models of text-image relations: Cheong's Generic Structure Potential (henceforth GSP) (2004) and Martinec \& Salway's System of Text-Image Relations (2005). Both approaches complement each other and are derived from previous work on the interplay of text and image. Likewise, both prove beneficial for getting a more clear understanding of advertisement as a form of discourse.

\section{6-1- Generic Structure Potential (GSP):}

GSP is a systemic-functional framework that contributes to the articulation of meaning in multi-semiotic texts. Cheong (1999) proposes a system that is concerned with investigating meaningmaking in print advertisements through presenting lexicogrammatical strategies for Ideational, Textual and Interpersonal meaning. The primary principle behind its development is that

...to limit text analyses to only the linguistic aspect and disregard the non-linguistic features such as graphs and diagrams is tantamount to annihilating the efflorescence

\section{ELLS VoI.9 No.I (549) SPU December 2018}


Text-Image Relations in Print Advertisement: A Multimodal Discourse Analysis

of meaning that can emerge from a multisemiotic analysis. (Cheong, 2004, p.163).

According to GSP, the print advertisement consists of a range of optional and obligatory visual and verbal elements. They will be listed and discussed below:

1- Lead: it is the most salient visual component. Its function is to draw the main focus of attention. It is shown with a variety of choices in terms of size, position, and/or color. The lead consists of two elements: the Locus of Attention (LoA) and the Complement to Locus of Attention (Comp. LoA):

2- Locus of Attention (LoA): it is the attention-arresting element and "embeds the central idea of the advertisement." (Ibid., p.165).

3- Complement to Locus of Attention (Comp. LoA): it refers to "the background or other visuals which are less salient than the LoA but complementing LoA" (Nugroho, 2009, p.74). In other words, it refers to components in the lead which are comparatively less salient than the (LoA). They functionally enhance the Interpersonal and Ideational salience of the LoA. In other words, the (Comp.LoA) plays a subordinate role, to channel and focus viewers' attention on particular aspects of the LoA. (Ibid., p. 169)

4- Display: it is the "photographic Display of the product or service in the advertisement" (Ibid., p. 171), and it shows characteristics of the Lead. LoA can perform one of two functions: Explicit Display or Implicit Display. The former function is when the advertised product is in a tangible form. The latter, on the other hand, is when the product is expressed via symbolism. In other words, the image is about an intangible product or service which, in turn, "is given tangible form through another medium" (Ibid., p. 74).

5- Emblem: this element can be represented visually or linguistically. Visually, it is shown by the logo of the advertised product or service. Linguistically, it is represented via "the brand name of the product/service" (Cheong, 2004, p.171).

6- Announcement: it is the most salient linguistic item(s). "Ideationally, the Announcement captures and conveys the essence

ELLS Vol.9 No.I (550) SPU December 2018 
of an intended message the advertisers wish to foreground to the consumers" (Ibid., p. 173).

7- Enhancer: this element consists of linguistic items only. It "builds on or modifies the meaning emanating from the interaction between the Lead and the Announcement. Interpersonally, its function is to persuade and influence viewers to purchase the product. Thus, the Enhancer contains Interpersonal lexis..., which carry an attitudinal and/or affective thrust" (Ibid.).

8- Tag: this element includes additional information about the product/service that is not mentioned in the Enhancer. They are one line in small print and are usually realized by an additional clause, phrase, non-finite, ellipted subject and a finite element.

\section{6-2- Martinec \& Salway's System of Text-Image Relations:}

Martinec \& Salway (2005) present a generalized system of the relations that hold between the text and the image in different genres of multimodal discourse. "The two modes appear separate yet integrated in both semantics and form." (Martinec \& Salway, 2005, p. 338). The system mainly emphasizes the semantic relations and their perceivable realizations where "both modes are in mutual relationship; the text serves the image, the image serves the text, or where both are equally dependent or independent of each other." (Ibid.). It draws on systemic functional linguistics and semiotics as its theoretical and descriptive framework. Each will be briefly outlined in the coming two sections.

\section{6-2-1- Halliday's Systemic Functional Grammar:}

Linguistics has witnessed several changes and developments in its trends, orientations, and subjects of study. The current theories of grammar are distinguished in accordance to the consideration of syntagmatic versus paradigmatic relations that hold between the linguistic items. "Linguistic items are said to be syntagmatically related when viewed as linear sequence and paradigmatically related when viewed as potential substitutes for their similarly positioned counterparts within the given sequence." (Bavali \& Sadighi, 2008,

\section{ELLS Vol.9 No.I (551) SPU December 2018}


Text-Image Relations in Print Advertisement: A Multimodal Discourse Analysis

p. 11). The latter view has given rise to Halliday's Systemic Functional Grammar (SFG).

In (SFG), language is the means for conveying meaning and grammar is a means for creating such intended meaning, rather than a set of rules. In other words, language is not a set of structures/forms that should be produced correctly. Language is essentially the knowledge of these structures/forms and how to use them to get the right meaning across and achieve particular social purposes or functions.

Systemic theory gets its name from the fact that the grammar of a language is represented in the form of system networks, not as an inventory of structures. Of course, structure is an essential part of the description; but it is interpreted as the outward form taken by systemic choices, not as the defining characteristic of language. (Halliday, 1985, p. 23)

Text is "any instance of language, in any medium, that makes sense to someone who knows the language." (Ibid., p.18). The analysis of the text involves the study of its context and type (register and genre). Context significantly contributes to the process of meaning-making. It has THREE categories, namely, field, tenor and mode. Field is concerned with what is going on in the situation. Tenor is who is participating in the situation in terms of their played roles and the invested values. Mode is the role played by the language and the various semiotic systems in the situation. (Ibid., p. 34).

The unit of analysis is the clause. Halliday distinguishes THREE distinct functions within the clause:

1) Theme (psychological subject): it is the concern of the message conveyed by the clause.

\section{ELLS VoI.9 No.I (552) SPU December 2018}


2) Subject (grammatical subject): "that of which something is being predicated (that is, on which rests the truth of the argument)." (Ibid., p. 55).

3) Actor (logical subject): "the doer of the action." (Halliday, 1985, p.55).

The significance of such a distinction is that each function constitutes a layer of the overall meaning of the clause. They specify certain functions performed by the clause as follows:

1) The clause as a message: the clause conveys information, and theme is 'the element the speaker selects for 'grounding' what he is going to say." (Ibid., p. 83).

2) The clause as an exchange: the clause is a form of interaction between the producer and the receiver. Subject is "the element the speaker makes responsible for the validity of what he is saying." (Ibid.)

3) The clause as a representation: the clause represents our knowledge of the world. The actor is" the active participant in that process." (Ibid.).

The three layers of meaning are embodied within the structure of the clause and they are referred to as Metafunctions in the systemic account of grammar.

\section{6-2-1-1- Metafunctions:}

Lexico-grammar is analyzed into three broad metafunctions: ideational, interpersonal, and textual. The analysis of the clause in terms of its metafunctions yields a different kind of structure that is, in turn, composed from a different set of elements, as is outlined in figure (1).

It is noteworthy that the three types of structures "are mapped on to one another to produce a single wording." (Ibid., p.88). Each of the above metafunctions will be discussed below.

\section{ELLS Vol.9 No.I (553) SPU December 2018}


Text-Image Relations in Print Advertisement: A Multimodal Discourse Analysis

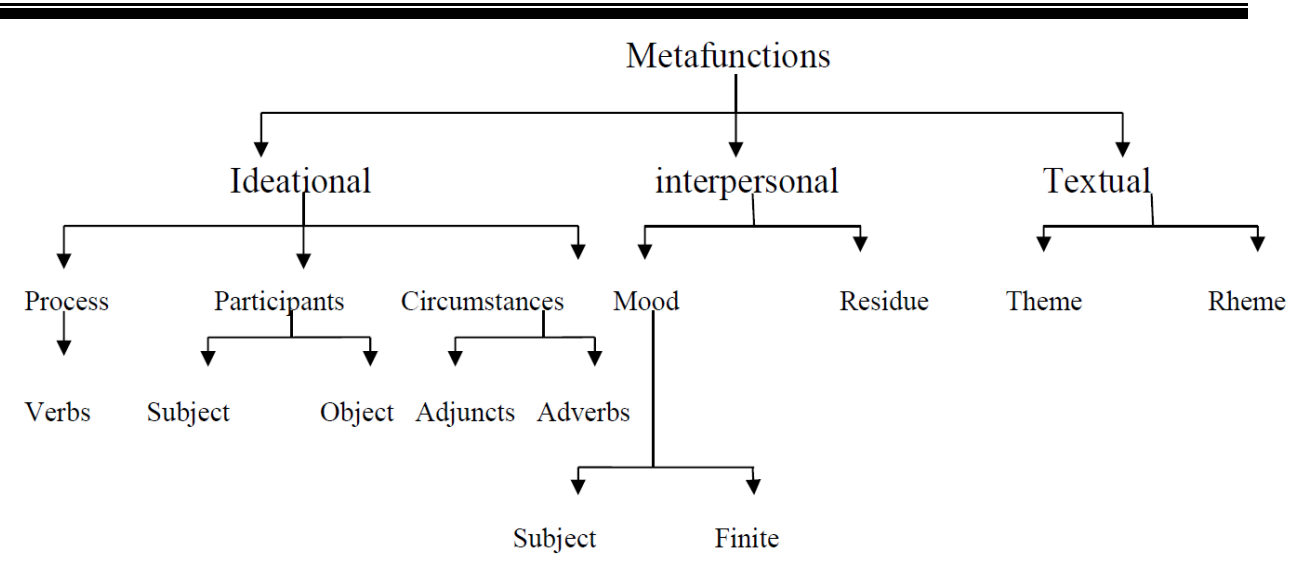

Figure (1): Clause Metafunctions and Components

The ideational metafunction is analyzed in terms of transitivity system. The clause consists of a process, which is regarded as the 'embryo' of the clause. (Bakuuro, 2017, p.213). The process (denoted by the verb) is one of the following types:

1) Material process: it is the process of doing and happening including actions, activities, and events. The following is an example: The policeman haunted the demonstrator. 'The policeman' is the actor, 'hunted' is the process (material), and 'the demonstrator' is the goal.

2) Mental process: it is the process of sensing, perception, cognition, intention, and emotion. For example, in 'She saw them', 'she' is the sensor, 'saw' is the process (mental), and 'them' is the phenomenon.

3) Relational process: its function is to characterize and identify something or someone. This process "is concerned with the relationship set up between two concepts or things." (Bavali \& Sadighi, 2008, p.16). it is expressed in one of two modes: Attributive or Identifying. For example, in 'Edward is clever', 'Edward' is the carrier, 'is' is the process (attributive relational), and 'clever' is the attribute. In 'Mary is the dentist', 'Mary' is the carrier, 'is' is the process (identifying relational), and 'the dentist' is the identifier.

\section{ELLS Vol.9 No.I (554) SPU December 2018}


4) Behavioral process: it is concerned with the psychological and physiological behavior such as smiling, coughing, laughing, breathing, and the like. For example, in 'John smiled', 'John' is the behaver and 'smiled' is the process (behavioral).

5) Verbal process: it is the process of 'saying'. Generally, it subsumes "any kind of symbolic exchange of meaning." (Halliday, 1985, p.129). For example, 'She told me a story', 'she' is the sayer, 'told' is the process (verbal), 'me' is the receiver, and 'a story' is the verbiage (i.e. the message itself).

6) Existential process: it depicts that something exists or happens and is generally denoted by 'There'. For example, 'There was no choice', 'there' is subject filler (i.e. it has no meaning or identified function), 'was' is the process (existential), and 'no choice' is the existent.

\section{6-2-2- Kress \& van Leeuwen's grammar of visual design:}

In a world that is characterized by technological advances, the images become a basic component of texts and a significant means of communication. 'Literacy', which essentially denotes the interpretation of written texts, has evolved to 'visual literacy'. The latter refers to "the processes of interpretation, negotiation, and meaning-making that are related to understanding the information presented in the form of an image." (Thuy, 2017, p.164).

Images, within a multimodal text, re-present reality. They are regarded as an interpretation of, rather than a reflection of, reality. This entails a need for a structure or a pattern that can be employed to interpret the meaning of visual texts. Kress and van Leeuwen (2006) offer the first systematic and comprehensive account of the grammar of visual design. They examine the ways in which images communicate meaning. According to them, "in order to function as a full system of communication, the visual, like all semiotic modes, has to serve several representational and communicational requirements." (Kress \& van Leeuwen, 2006, p.41).

\section{ELLS Vol.9 No.I (555) SPU December 2018}


Text-Image Relations in Print Advertisement: A Multimodal Discourse Analysis

They have utilized Halliday's theoretical notion of 'metafunctions'. They can be extended to visual communication. They identified three analogous metafunctions, namely, representational, interactive, and compositional. They are summarized in figure (2). Each will be discussed briefly below.

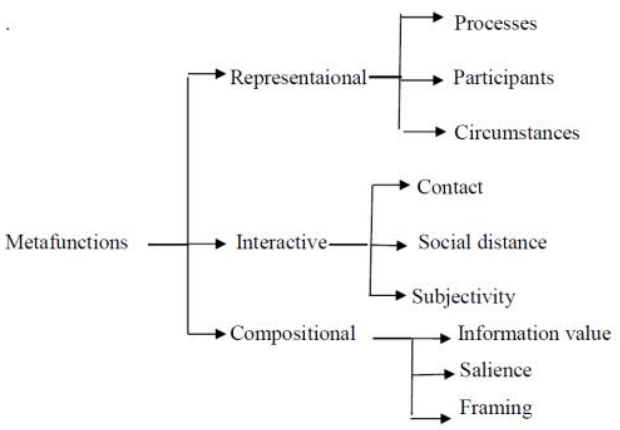

Figure (2): Kress \& van Leeuwen's (2006) metafunctional framework

1) Representational meaning: the visual image fulfills the function of the representation of the experiential world. In other words, the employed mode represents aspects of the world as humans experience it. However, the structure of the mode does not simply reproduce the structure in reality. Rather, visual structures "produce images of reality which are bound up with the interest of the social institutions, within which the images are produced, circulated, and read." (Kress \& van Leeuwen, 2006, p.47). Two kinds of images are distinguished: the narrative image and the conceptual image.

a) Narrative image: it is an image where "participants are connected by a vector...they are represented as doing something to or for each other." (Ibid., P.59). For instance, a narrative image unfolds actions, events, change processes, and transitory spatial arrangements.

\section{$\begin{array}{llllll}\text { ELLS Vol.9 No.I } & \text { (556) SPU December } 2018\end{array}$}


It involves four processes: action process, reactional process, speech and mental process, and conversion process.

b) Conceptual image: it represents the participants "in terms of their more generalized and more or less stable and timeless essence, in terms of class, or structure or meaning." (Ibid., p.79). Such a type never has a vector and involves three kinds of processes: classificational process, analytical process, and symbolic process.

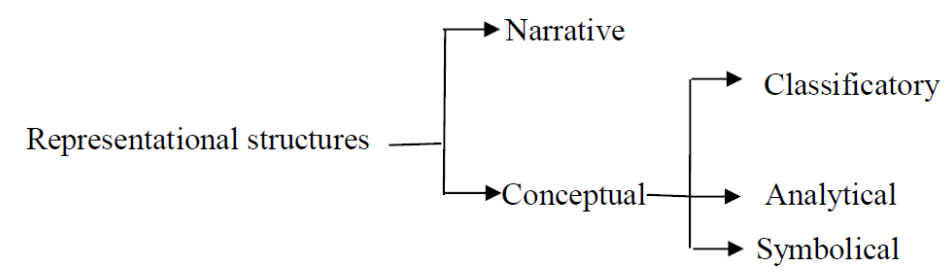

Figure (3): Main types of visual representational structure

(Source: Kress \& van Leeuwen, 2006, p.59)

2) Interactive meaning: it designates the roles played by the visual mode in constituting and maintaining the interaction between the producer and the viewer of the image. The visual mode is produced within "the context of social institutions which...regulate what may be 'said' with images, how it should be said, and how it should be interpreted." (Kress \& van Leeuwen, 2006, p.114). Images can be examined terms of three aspects: contact, social distance, and attitude.

3) Compositional meaning: it is related to "the way in which the representational and interactive elements are made to relate to each other; the way they are integrated into a meaningful whole." (Kress \& van Leeuwen, 2006, p.176). three interrelated systems connect the representational and interactive meanings:

\section{ELLS Vol.9 No.I (557) SPU December 2018}


Text-Image Relations in Print Advertisement: A Multimodal Discourse Analysis

a) Information value: this is through the placement of images within specific 'zones'.

b) Salience: it refers to how elements, such as size, color, and sharpness draws the viewer's attention.

c) Framing: this is whether "the presence or absence of framing devices...disconnects or connects elements of the image." (Ibid., p.177).

\section{6-3- Martinec \& Salway's System:}

\section{6-3-1- Status:}

Status relations specify the relative importance (or the relative dominance) of each mode to the interpretation of the other. Text and image can be equal or unequal in status. When the relative imagetext status is equal, a whole image is related to a whole text. The equal relation is further divided subdivided into: independent and complementary.

Both text and image are independent when: 1) the whole image is related to the whole text. 2) The information they provide exist in parallel, i.e. each mode has its own separate process configuration without depending on each other. 3) There are no signs of one modifying the other.

Text and image are complementary when: 1) whole image is related to the whole text. 2) Both modes depend on and modify each other. 3) The two modes together form one single process configuration.

Image and text are unequal when "one of them modifies the other. The modifying element is considered to be dependent on the modified one." (Martinec \& Salway, 2005, p. 343). In other words, one mode (either the text or the image) is subordinate to the other. Text-image subordination is summarized as follows:

Image subordination is realized by the image relating to a part of the text. Text subordination is realized by deixis from text to image, either by reference items or present tense combined with material or behavioral processes (Ibid., p. 348). The status dimension can be outlined as shown in figure (2) below.

\section{ELLS Vol.9 No.I (558) SPU December 2018}




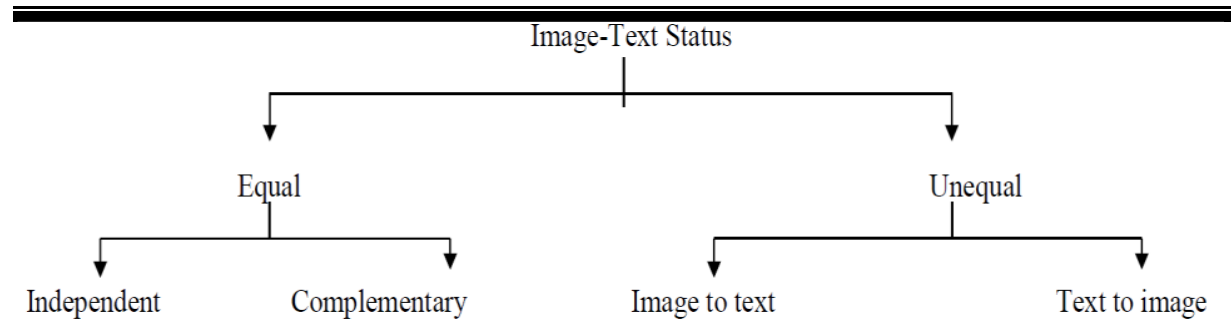

\section{Figure (4): Image-Text Status}

\section{6-3-2- Logico-semantic relations:}

Following Halliday's grammar, Martinec \& Salway specify two main types of semantic relations that can hold between image and text, namely, Expansion and Projection. Expansion is the relation that holds between represented events in the non-linguistic experience (Martinec \& Salway, 2005, p. 349). It is further subdivided into three subsidiary categories: Elaboration, Extension, and Enhancement. Each will be discussed below:

1) Elaboration: it holds when one mode provides a more detailed description of the other mode. The elaborating mode does not necessarily provide new information but elaborates on the information in the elaborated mode. Elaboration is further divided into Exposition and Exemplification.

a) Exposition: the text and image are of the same level of generality. In other words, the two modes present the same information but in a different form or a presentation method.

b) Exemplification: in this relation the levels of generality are different, i.e. either the text or the image can be more general (Ibid., p. 350). It is one way of expanding the information by citing an example of the information.

2) Extension: it is a relation in which "either the one or the other adds new, related information... we consider the information an addition because it goes beyond what is represented" (Ibid.). However, the information in the two modes needs to be related.

\section{ELLS Vol.9 No.I (559) SPU December 2018}


Text-Image Relations in Print Advertisement: A Multimodal Discourse Analysis

3) Enhancement: in a relation of enhancement, one of the modes qualifies the other circumstantially, i.e. by time (one of the modes can enhance the other by explaining when something happened), by place (one of the modes enhances the other by showing a spatial location where the enhanced mode takes place), or by reason/purpose (one of the modes gives the reason for the event or process in the enhanced mode).

Projection, the other main type of logico-semantic relations, deals with relations between "events that have already been represented... Projection is useful to account for cases when content that has been represented by text or image is re-represented in the other mode" (Martinec \& Salway, 2005, p.349). Examples of projected content include diagrams and comic strips, where the most important information (meaning) is re-expressed in a visual form. Projection embraces the following two subtypes: Locution and Idea.

1) Locution: it is a projection of wording, i.e. the quotation of the exact wording. In language, if the represented experience is quoted, verbal processes are employed and the exact words are enclosed between quotation marks.

2) Idea: it is a projection of what has been thought and "it tends to be projected by a mental process and the meanings rather than exact words are reported" (Ibid.). In language, if the represented experience is a thought, mental processes are employed.

\section{7-Analysis:}

\section{7-1- Ciggie Bruise: Commercial advertisement}

\section{7-1-1- Introductory:}

The advertisement is one of a series of ads in a campaign for the American tobacco company "Tareyton". The campaign was created by BBDQ advertising agency in the 1960s. The target of the company was to motivate and enhance the sense of loyalty of Tareyton smokers.

\section{$\begin{array}{llllll}\text { ELLS Vol.9 No.I } & \text { (560) SPU December } 2018\end{array}$}


Both modes, the image and the text, are employed in the advert. It is divided into THREE sections; each has its own image and text: the upper section, the right lower section, and the left lower section. Following is an analysis of each section:

The upper section takes up more than half the space of the advertisement. The Lead is the image of a female model representing Tareyton smokers. She holds a Tareyton cigarette in one of her hands. One of her eyes is Tareyton Cigarette black as if she has been hit or had a fight. She seems to have won the fight because she smiles and looks satisfied.

Both the female model and the cigarette constitute the Locus of Attention (LoA) as it encapsulates the central idea. The bruised woman holding the cigarette becomes the entry point for the advertisement viewer. This image is the most salient in terms of size and position. The woman is the actor in an action process: the woman is smoking a cigarette. The cigarette is the goal. Likewise, the woman is the carrier of the attribute 'smoker' in an analytical relation. She represents the whole class of Tareyton smokers. Also, the woman is the reacter in a reactional process. She has a direct eye contact with the viewer. This has two related functions: it creates a visual form of direct address and it constitutes an image act by which the producer does something to the viewer. It 'demands' the viewer to intrigue his imagination and infer the meaning.

The slogan "Us Tareyton smokers would rather fight than switch" forms the Primary Announcement. The text "Join the unswitchables... aggressively loyal" is the Enhancer. It is written in the form of a short paragraph in a smaller font size than the Primary Announcement. An abundance

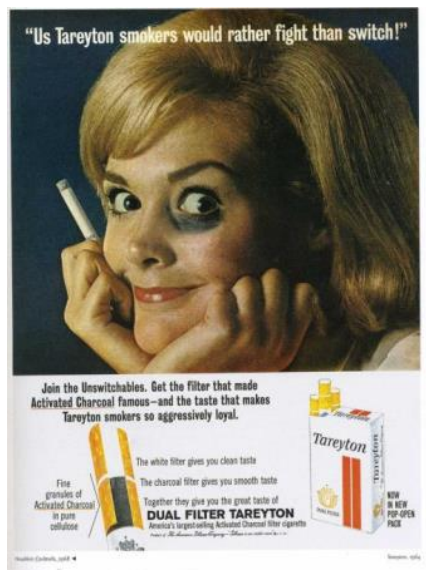
of interpersonal lexis (bold-faced and underlined) is employed in the

\section{ELLS Vol.9 No.I (561) SPU December 2018}


Text-Image Relations in Print Advertisement: A Multimodal Discourse Analysis

Enhancer to persuade and influence the viewers to purchase the product. The Transitivity processes shown in the Enhancer, through the employment of Material processes, clarifies the interplay between the lead (image) and the primary announcement (text).

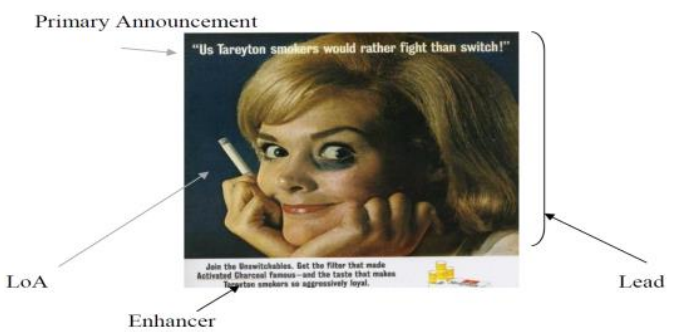

Figure (5): Tareyton Advertisement Upper Section: Verbal and Visual Elements

7-1-2- Analysis:

\begin{tabular}{|c|c|}
\hline Text & Image \\
\hline $\begin{array}{l}\text { The Primary } \\
\text { Announcement: } \\
\text { "Us Tareyton smokers } \\
\text { would rather fight than } \\
\text { switch" }\end{array}$ & $\begin{array}{l}\text { Locus of Attention } \\
\text { (LoA): }\end{array}$ \\
\hline \multicolumn{2}{|c|}{$\begin{array}{l}\text { Status: } \\
\text { Equal/Independent: the whole image is related to the whole text, i.e. } \\
\text { the model represents smokers, the bruise represents the result of a } \\
\text { fight, and holding the cigarette represents loyalty to the brand of the } \\
\text { cigarette. Both the text and image are in parallel. }\end{array}$} \\
\hline $\begin{array}{l}\text { Logico-semantic relation: } \\
\text { Enhancement: The image } \\
\text { providing the effect. Rea } \\
\text { understands the reason for } \\
\text { and the reason that she is } \\
\text { weakened if it was used }\end{array}$ & $\begin{array}{l}\text { enhances the text circumstantially by } \\
\text { ding the text ensures that the viewer } \\
\text { the black bruise around the model's eye, } \\
\text { content. The effect of the text would be } \\
\text { in isolation without the accompanying }\end{array}$ \\
\hline
\end{tabular}

ELLS Vol.9 No.I (562) SPU December 2018 
image.

Status:

Unequal: the image is subordinate to and modifies the text. The text can be understood in isolation. It dominates the image.

Logico-semantic relation:

Enhancement: The text enhances the image by providing the cause of the effect outlined in the image. "The filter" and "the taste" are the main reason for not changing the tobacco, and consequently having a fight over switching.

Table (1): Analysis of Text-Image Relations in Tareyton Advertisement

The following figure shows the right lower section of the advert:

\section{Display}

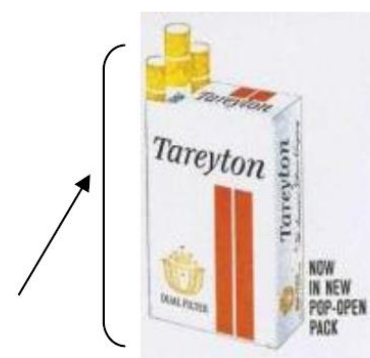
(a) 
Text-Image Relations in Print Advertisement: A Multimodal Discourse Analysis

read as: Tareyton (as shown in image) is in new pop-open pack (as the one displayed in the image).

\begin{tabular}{|l|l|}
\hline Text & Image \\
\hline $\begin{array}{l}\text { Primary Announcement: Now in } \\
\text { new pop-open pack }\end{array}$ & Display: \\
\hline $\begin{array}{l}\text { Status: } \\
\text { Unequal: the text is subordinate to the image. The image can be } \\
\text { intepereted individually by the viewer. However, the text, when } \\
\text { read individually, needs clarification for its comprehension. }\end{array}$ \\
$\begin{array}{l}\text { Logico-semantic relation: } \\
\text { Elaboration: the image elaborates the intended meaning of the text. } \\
\text { The image does not provide additional information. Rather, it } \\
\text { clarifies on the information in the elaborated mode. }\end{array}$ \\
\hline
\end{tabular}

\section{Table (2): Text-Image Relations in Tareyton Advertisement: Right Lower section}

The left lower section of the ad shows the Display. It is the cross section of the tip of a Tareyton cigarette. The image is the carrier of the attributes 'clean, smooth, and great'. Also, the filter is in analytic process where it instantiates an example of the filter and iots composition. The advertiser's basic goal is to let the viewer actually notice the structure of the unique filter which distinguishes Tareyton cigarettes from other similar products. The Enhancer is a paragraph that discusses the structure of the filter.

\section{ELLS Vol.9 No.I (564) SPU December 2018}




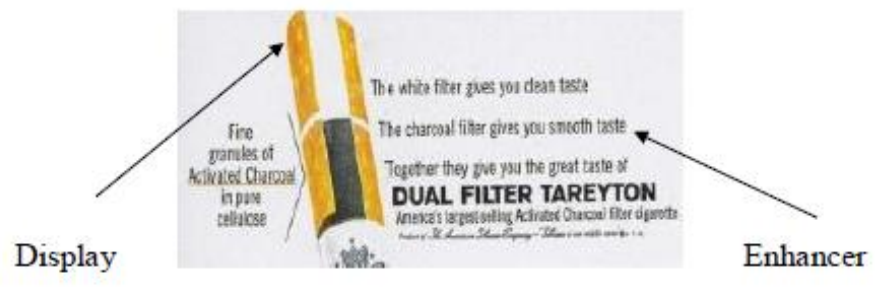

\section{Figure (7): Tareyton Advertisemnt Left Lower Section: Verbal and Visual Elements}

\begin{tabular}{l}
\hline Text \\
Enhancer: \\
The white filter gives you clean \\
taste. The charcoal filter gives \\
you smooth taste. Together they \\
give you the great taste of DUAL \\
FILTER TAREYTON \\
America's largest selling \\
Activated Charcoal filter \\
cigarette \\
Status: \\
Equal/Independent: the whole image is related to the whole text. \\
The information delivered in both modes exist in parallel. \\
\hline Logico-semantic relation: \\
Image \& clauses (a) and (b): Projection: both modes are at the same \\
level of generality. Both present the same information but in \\
different forms. \\
Image \& clause c: Extension: the text provides further information \\
than what is outlined by the image; the text tells the reader that it is \\
the unique filter that makes TAREYTON stand out. \\
Image \& clause d: Exposition: both the image and the text represent \\
the same information. They are at the same level of generality. \\
\hline
\end{tabular}

\section{ELLS VoI.9 No.I (565) SPU December 2018}


Text-Image Relations in Print Advertisement: A Multimodal Discourse Analysis Enhancer: Fine granules of Display: Activated Charcoal in pure cellulose

Status: Unequal: the image is subordinate to the text. it cannot be interpreted individually apart from the text.

Logico-semantic relation: Pojection: the content of the text is rerepresented in the image. The image is a diagram that explains the content of the text.

Table (3): Text-Image Relations in Tareyton Advertisement: Left Lower section

\section{7-2- Axle Grease Shampoo: Commercial Advertisement}

\section{7-2-1- Introductory}


The advertisement is about a hair product called (Axle Grease Shampoo). Axle grease is a slang term for heavy hair pomade that is petroleum-based. The advertiser's message is to encourage viewers to purchase the product. The intended audience is basically people who have a problem with their dry hair and wish to control it into a good look. The two modes, the text and the image, are employed in the ad. It is

AUXLE GRIEASOHE SHAMPOO

It's Great!

A shampoo so good you only have to use it once....EVER!

Ultra-moisturizing, hydrocarbon enriched formula, leaves dry and damaged hair fragrant.

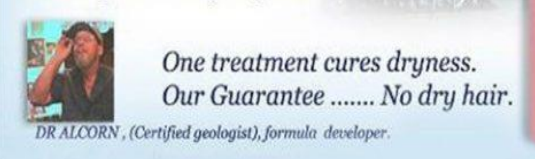
AXLE GREASE SHAMPO Givi: divided vertically into two sections: the right-hand section and the left-hand section. The textual element occupies the left section, whereas the imagery occupies the left section.

Axle Grease Shampoo Advertisement

The ad starts with the Primary Announcement1, which is the product's slogan,

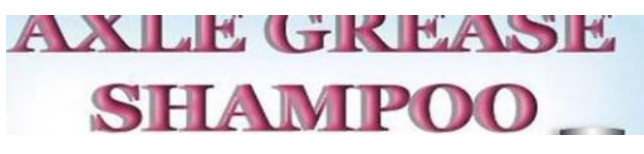
printed in the largest font and in a different color (pink color) from the rest of the text. It is placed at the top of the ad to catch the reader's attention to the coming message.

Following the Primary Announcement is the Primary Announcement2. It is printed in a It's Great! big font and refers back to the Axle Grease Shampoo through the usage of the $3^{\text {rd }}$ person pronoun 'it'. The text mentions the basic distinguishing feature of the shampoo; that is, it contains natural ingredients.

\section{ELLS VoI.9 No.I (567) SPU December 2018}


Text-Image Relations in Print Advertisement: A Multimodal Discourse Analysis

Below the Primary
Announcement1 is the A shampooso good
following
component, which is the use it once....EVER!

Secondary Announcement. It extends the meaning of the Primary Announcement2: the shampoo is so effective that if it is applied once, it will terminate the problem of dry hair permanently.

Following is the Enhancer. It consists of one TWO sections. The first consists of a statement that clarifies the reason for the goodness of

Ultra-moisturizing, hydrocarbon enriched formula, leaves dry and damaged hair fragrant. Axle Grease shampoo: it is the qualities and attributes of its formula that leaves the hair fragrant. The mention of this reason distinguishes Axle Grease from other similar products and, consequently, encourages viewers to choose it.

The second part of the Enhancer consists of a quoted speech said by the shampoo formula developer, Dr. Alcorn, certified geologist. This part has its own image (i.e. the picture of Dr. Alcorn) and text (i.e. Dr. Alcorn's quoted speech). The image functions as the Lead (LoA) of this section, where Dr. Alcorn is the sayer in a speech process. The text is

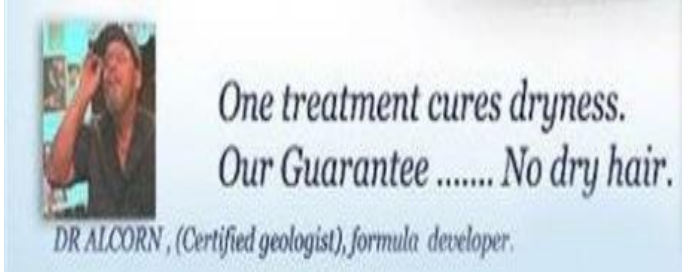
the Primary Announcement which emphasizes the effectiveness of the product through the usage of "cures dryness ... No dry hair". This is a technique employed by the advertiser to persuade and encourage viewers to trust and, consequently, purchase the product.

The visual component located in the left vertical section consists of the Lead which shows a big shampoo bottle. The bottle functions as the Locus of Attention (LoA1) which plays the role of the Explicit Display of the advertised product. It is a static image that is in analytical process. The shampoo bottle is the carrier. The size and the frame distance are significant dimensions in the interactive

\section{ELLS Vol.9 No.I (568) SPU December 2018}


meaning. The shampoo bottle extends from the top of the ad to the bottom and is placed in the foreground in a close-up shot. These techniques serve to draw the viewers' attention the shape and color of the product: "the alluring sensory quality of the advertised product as a whole...takes precedence over more dispassionate scrutiny of the possessive attributes." (Kress \& van Leeuwen, 2006, p.90).

The Complementary to Locus of Attention (Comp.LoA) is the background behind the shampoo bottle. It is printed in a lighter hue. It shows an oil field where the extraction of petroleum takes place. Axle grease is extracted from petroleum. Thus, the background represents the source of the natural ingredients of the shampoo. The employment of the picture in this way serves as a proof or evidence of the claim made in the text: 'all natural ingredients'.

Both images 'offer' information that is necessary for the viewer to get persuaded by the product. Also, they are related to each other and to the conveyed meaning of the fore-mentioned linguistic components.

\section{7-2-2- Analysis:}

\begin{tabular}{|l|l|}
\hline Text & Image \\
\hline The Primary Announcement1: & (LoA1): Explicit \\
& \\
& \\
& \\
& \\
\hline $\begin{array}{l}\text { Status: Equal/Independent: the whole image is related to the whole } \\
\text { text. Both can be understood individually. }\end{array}$ \\
\hline
\end{tabular}

ELLS Vol.9 No.I (569) SPU December 2018 
Text-Image Relations in Print Advertisement: A Multimodal Discourse Analysis

Logico-semantic relation: Elaboration: the text is written in the same font face and the same font color as the name and color of the image of the shampoo bottle. No new element is added by the text when related to the image, nor is a new ideational element added by the image if related to the text. The recipient links the text with the image and gains knowledge of the product and, at the same time, is motivated to learn about it.

The Primary Announcement2: $\quad$ (LoA1): Explicit It's Great!

All Natural Ingredients Display:

Status: Unequal: the text is subordinate to the image. The recipient cannot understand what the $3^{\text {rd }}$ person pronoun refers to unless it is related to the image of the shampoo. In addition, the phrase 'all natural ingredients' can be understood in relation to different products. However, the image confines the recipient's ideas to the shampoo.

Logico-semantic relation: Extension: the text adds new, related information to the image. The recipient knows that the shampoo represented by the image has a good quality

Enhancement: the text qualifies the image by mentioning the reason of the goodness of the shampoo. It is made from all natural ingredients.

ב-

ELLS Vol.9 No.I (570) SPU December 2018 
Yasmin M. El-Sayed

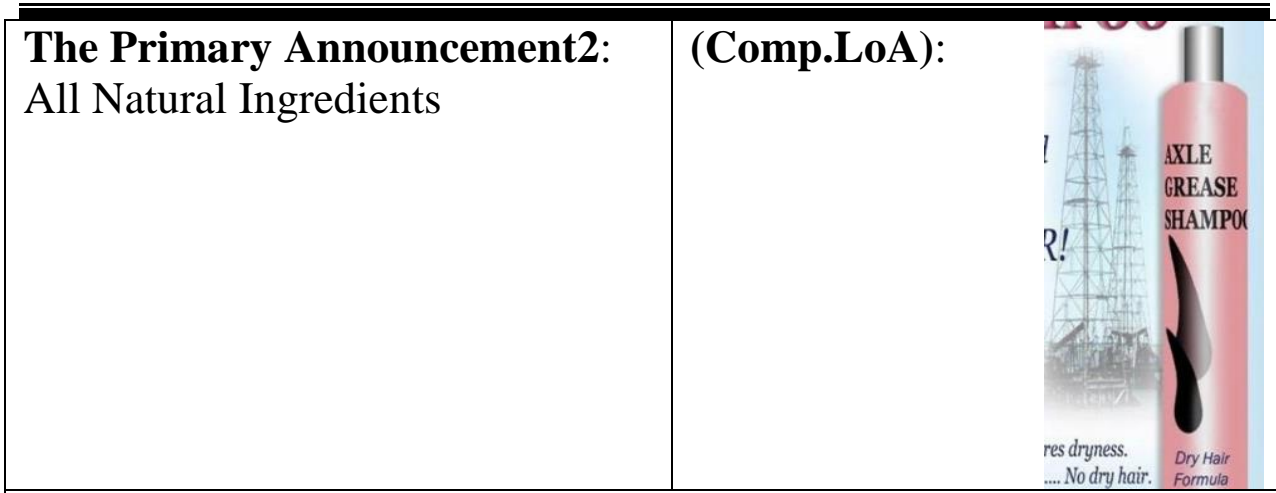

Status: Equal/Complementary: both the image and the text are required for the successful communication of information. The two modes modify and depend on each other.

Logico-semantic relation: Enhancement: the image enhances the text by providing the spatial location from which the natural ingredients are extracted.

\begin{tabular}{l|ll}
\hline The Secondary Announcement: & (LoA1): Explicit \\
A shampoo so good you only have & Display: &
\end{tabular} to use it once ... EVER!

AXLE

GREASE

SHAMPOC

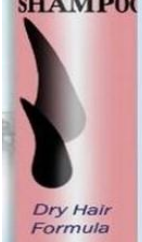

Status: Equal/Complementary: the whole image is related to the whole text. Both modes modify each other. The image of the shampoo bottle represents the product that is characterized, by implicit relational process in the text, as 'so good'

Logico-semantic relation: Extension: the text extends the information on the image, which is the shampoo. The extending information in the text cannot be seen directly in the image and is therefore new information.

\section{ELLS Vol.9 No.I (571) SPU December 2018}


Text-Image Relations in Print Advertisement: A Multimodal Discourse Analysis

\begin{tabular}{|c|c|c|}
\hline & $\begin{array}{l}\text { First Section: } \\
\text { Ultra-moisturizing, } \\
\text { hydrocarbon enriched } \\
\text { formula, leaves dry and } \\
\text { damaged hair fragrant. }\end{array}$ & $\begin{array}{lll}\text { (LoA1): } & \text { Explicit } \\
\text { Display: } & & \\
& & \text { AXLE } \\
\text { GREASE } \\
\text { SHAMPOC }\end{array}$ \\
\hline \multirow{5}{*}{ 昰 } & \multicolumn{2}{|c|}{$\begin{array}{l}\text { Status: Equal/Complementary: the whole image is related to } \\
\text { the whole text. The text modifies the image. The 'ultra- } \\
\text { moisturizing, hydrocarbon enriched formula' is referred to by } \\
\text { the image of the shampoo bottle. }\end{array}$} \\
\hline & \multicolumn{2}{|c|}{ Logico-semantic relation: Extension } \\
\hline & $\begin{array}{l}\text { Second Section: } \\
\text { One treatment cures dryness. } \\
\text { Our guarantee..... No dry } \\
\text { hair. } \\
\begin{array}{l}\text { Dr ALCORN, (certified } \\
\text { geologist), } \\
\text { developer. }\end{array}\end{array}$ & Lead: \\
\hline & \multicolumn{2}{|c|}{$\begin{array}{l}\text { Status: Equal/Complementary: the image complements the } \\
\text { meaning of the quoted text as it clarifies the sayer of the text. }\end{array}$} \\
\hline & \multicolumn{2}{|c|}{$\begin{array}{l}\text { Logico-semantic relation: Projection/Locution: the text } \\
\text { represents the wordings said by Dr. Alcorn, who is shown by } \\
\text { the image. }\end{array}$} \\
\hline
\end{tabular}

Table (4): Axle Grease Shampoo: Status \& Logico-Semantic Relations

\section{ELLS VoI.9 No.I (572) SPU December 2018}


Yasmin M. El-Sayed

7-3- The Candies' Foundation: Non-commercial advertisement 7-3-1- Introductory:

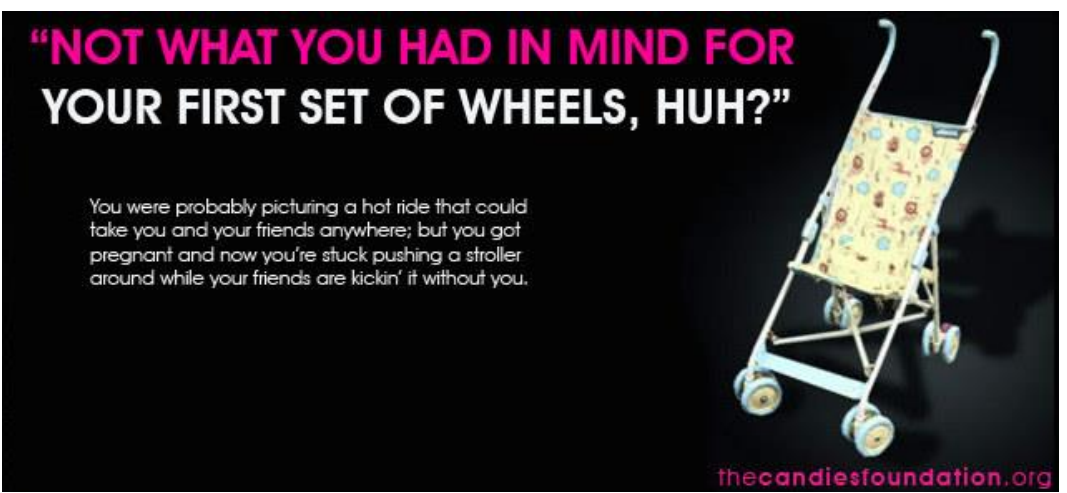

Candies' Foundation Advertisement

The Candies' foundation is a non-profit organization that was founded in 2001. Its mission is to raise awareness of the devastating consequences of teenage pregnancy. The above advertisement is one of a series of advertising campaign.

According to Cheong (2004), The Lead is "the most interpersonally Salient... and thus this element is first approached by viewers." (p.177). Therefore, the sole represented participant of the advertisement is the visual component, the Lead, which engages the viewer. The reader's attention at is focused on the baby stroller which functions as (LoA). It is a static image that functions as the carrier in an analytical relation. It's a member of a class of baby requirements and needs.

\section{$\begin{array}{llllll}\text { ELLS Vol.9 No.I } & \text { (573) SPU December } 2018\end{array}$}


Text-Image Relations in Print Advertisement: A Multimodal Discourse Analysis

There can be several mental interpretations as to why this picture is found in the advert. However, the rhetorical

You were probably picturing a hot ride that could take you and your friends onwhere; but you got pregnant and now you're stuck pushing a stroller around while your friends are kickin' it without you. question: "Not what you had in mind for your first set of wheels, huh?" which functions as the Primary Announcement, directs the viewer's comprehension path. There is a mental, thinking process between the Lead and the Primary Announcement, where the stroller is the phenomenon that is NOT thought about. For teenagers, the expression 'first set of wheels' represents the first real automobile that he/she owns. The stroller is basically used by parents to carry their children. It is remotely anticipated by a teenager to have a stroller as his/her first car. There is a Bidirectional Investment between the text and the image, i.e. "...Bidirectional Investment of meaning from the lexicogrammatical choices in the Announcement to the visual in the Lead and vice versa." (Ibid., p. 178). The usage of the picture "deliberately disappoints or runs counter to the regular look of things" (Stockl, 2009 , p. 15). Thus, the viewer is invited to figure out the link between the image and the question.

The following component in the ad is the Enhancer. It is a paragraph that directly follows the Primary Announcement. However, it is written in a smaller font. It gradually explicates the reason for displaying the stroller. It is that 'You' (supposedly a teenager) are pregnant and is expecting a baby at a very young age. Instead of having a nice ride with friends, 'You' will be pushing the stroller.

The enhancer performs two functions: first, it establishes a link between the image in the Lead and the text in the Primary Announcement. Second, it details the advertiser's argument why this idea or service is worth considering. The advertiser's goal is to attempt to convince potential viewers (teenagers or teenagers' parents) of the consequences of teen pregnancy.

\section{ELLS Vol.9 No.I (574) SPU December 2018}


Thus, the advertiser employs contradictory mental and material processes to contradict the imagination and reality. For example, in reference to the imagined situation, the advertiser uses the mental process 'picture' and the phenomenon 'a hot ride'. In describing the real situation, the advertiser employs the material processes of 'got pregnant', 'stuck pushing a stroller' to depict the teenager's reality. The final linguistic component is the Call-and-Visit Information which is placed at right lower corner. It provides the viewer with the necessary contact information.

\section{7-3-2- Analysis:}

\begin{tabular}{|l|l|}
\hline Text & Image \\
\hline The Primary Announcement: & The Lead: (LoA): \\
Not what you had in mind for \\
your first set of wheels?
\end{tabular}

Status: Equal/Complementary: Both the image and the text are required for the successful communication of information. The text modifies the understanding of the image. Neither the text nor the image can be understood individually.

Logico-semantic relation: Exemplification: the image is an instance of the sort of ride a teenager parent is going to have.

\section{Enhancer:}

Clause 1: 'You were probably picturing a hot ride that could take you and your friends anywhere,'

Clause 2: 'but you got pregnant' Clause 3: 'and now you're stuck pushing a stroller around while your friends are kickin' it without you.'
The Lead: (LoA)

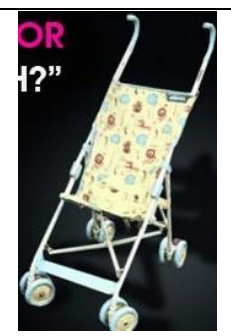

Status: Unequal: the image is subordinate to the text, i.e. it is related

$$
\begin{array}{llllll}
\text { ELLS Vol.9 No.I (575) SPU December } 2018
\end{array}
$$


Text-Image Relations in Print Advertisement: A Multimodal Discourse Analysis

to only a part of the text: 'you're stuck pushing a stroller'.

Logico-semantic relation:

Clause $1 \&$ the Lead: Exemplification: the represented participant in the image (the stroller) presents a more specific example (a member of a group). The text is more general than the image

Clause $2 \&$ the Lead: Enhancement: the text enhances the image by mentioning the reason for having a stroller as a ride, and not any other type of those expected for a teenager.

Clause $3 \&$ the Lead: Extension: the text adds related information that go beyond what is represented by the image.

Table (5): Candies' Foundation: Status \& Logico-Semantic Relations

\section{7-4- Coram Children's Legal Centre: Non-commercial advertisement}

7-4-1- Introductory:

Coram Children's Legal Centre is a UK charity that was launched in 1981. Its main mission is to promote and uphold children's human rights. The charity is named after Thomas Coram, a philanthropist and campaigner in England whose greatest achievement was the foundling hospital. The advert is about one of the services provided by Coram charity, which is to provide shelter for homeless children. The advertiser's intended message is to persuade the audience to donate for the cause.

\section{ELLS VoI.9 No.I (576) SPU December 2018}


Yasmin M. El-Sayed

The two modes are
employed in the advert. The
visual component consists of the
Lead. It consists of (LoA) which
shows a teenage girl who seems
to be cold, sad, needy and afraid.
The close-up shot allows the
viewer to view the girl's upper
part: to closely see her eyes and
that she seems cold. The girl is
the represented participant of the
ad; she is the carrier of symbolic
suggestive attributive. The
image serves to set the identity of

the participant as one of the

homeless young people. It allows the viewer to scrutinize the carrier's possessive attributes.

In addition, the participant is the reacter in a reactional process, where the phenomenon is not directly represented. It is implied that the girl's gaze directly addresses the viewer. This way the image is "more interactional and emotive than representational." (Kress \& van Leeuwen, 2006, p.89). The girl's gaze 'demands' that the viewer figures the source of sadness and attempts to help.

The other image shows a key chain in the shape of a house and has the name of the foundation printed on it. It is the carrier of a symbolic suggestive attributive process as it symbolizes the shelter provided by the charity. It functions as the Explicit Display of the service provided by Coram charity.

As per the linguistic component, it starts with the Primary Announcement: 'Life Support.'. It is the catch-phrase of the advert and is distinguished by its relative prominence in terms of size and font face. Directly below the Primary Announcement is the Enhancer, which consists of two paragraphs. It is marked by the usage of interpersonal lexis in order to persuade and influence the

\section{ELLS VoI.9 No.I (577) SPU December 2018}


Text-Image Relations in Print Advertisement: A Multimodal Discourse Analysis

viewer. Examples include 'unwanted, unloved, abused, frightened, help, vulnerable children, feel safe, loved' and so forth. They carry an affective thrust. The main function of the Enhancer is to detail the advertiser's argument as to why to continue reading about the service provided by Coram charity.

Following is the Call-and-Visit Information for the potential donors: 'Please text LIFE to 70707 to give $€ 3$ '. The following linguistic element is the Secondary Announcement. At the left bottom corner is the Emblem and tag.

7-4-2- Analysis:

\begin{tabular}{l}
\hline Text \\
Life Support
\end{tabular}

\section{ELLS Vol.9 No.I (578) SPU December 2018}


Yasmin M. El-Sayed

\begin{tabular}{|c|c|c|}
\hline & $\begin{array}{l}\text { Unwanted, unloved and } \\
\text { abused. Life for Katie has } \\
\text { been one of neglect. Living on } \\
\text { the streets, Katie felt } \\
\text { frightened and worthless. She } \\
\text { didn't know where she would } \\
\text { be sleeping each night, or } \\
\text { even if she would live to see } \\
\text { her } 17^{\text {th }} \text { birthday. }\end{array}$ & $\begin{array}{l}\text { The Lead: } \\
\text { (LoA) }\end{array}$ \\
\hline & $\begin{array}{l}\text { Status: Equal/Complementary: } \\
\text { required to convey the informa } \\
\text { text can be understood individ } \\
\text { girl named Katie. Her facial ex } \\
\text { 'frightened', 'worthless'. }\end{array}$ & $\begin{array}{l}\text { ooth the image and the text are } \\
\text { ion. Neither the image nor the } \\
\text { ally. The (LoA) represents the } \\
\text { pressions match the adjectives: }\end{array}$ \\
\hline & $\begin{array}{l}\text { Logico-semantic relation: Ex } \\
\text { meaning of the image by addin } \\
\text { as the gil's name, her feelings, }\end{array}$ & $\begin{array}{l}\text { ension: the text extends the } \\
\text { new, related information such } \\
\text { ad her worries. }\end{array}$ \\
\hline & $\begin{array}{l}\text { For young people like Katie, } \\
\text { thankfully, there is Coram. }\end{array}$ & $\begin{array}{l}\text { The Lead: } \\
\text { (LoA): }\end{array}$ \\
\hline \multirow{2}{*}{ 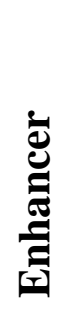 } & \multicolumn{2}{|c|}{$\begin{array}{l}\text { Status: Unequal: the text is subordinate to the image. It can be } \\
\text { understood in relation to the image which shows a homeless } \\
\text { female teenager. }\end{array}$} \\
\hline & \multicolumn{2}{|c|}{$\begin{array}{l}\text { Logico-semantic relation: Exemplification: the text is more } \\
\text { general than the image. The image provides an instance of the } \\
\text { children who need help and who are supported by Coram. }\end{array}$} \\
\hline
\end{tabular}

\section{ELLS Vol.9 No.I (579) SPU December 2018}


Text-Image Relations in Print Advertisement: A Multimodal Discourse Analysis

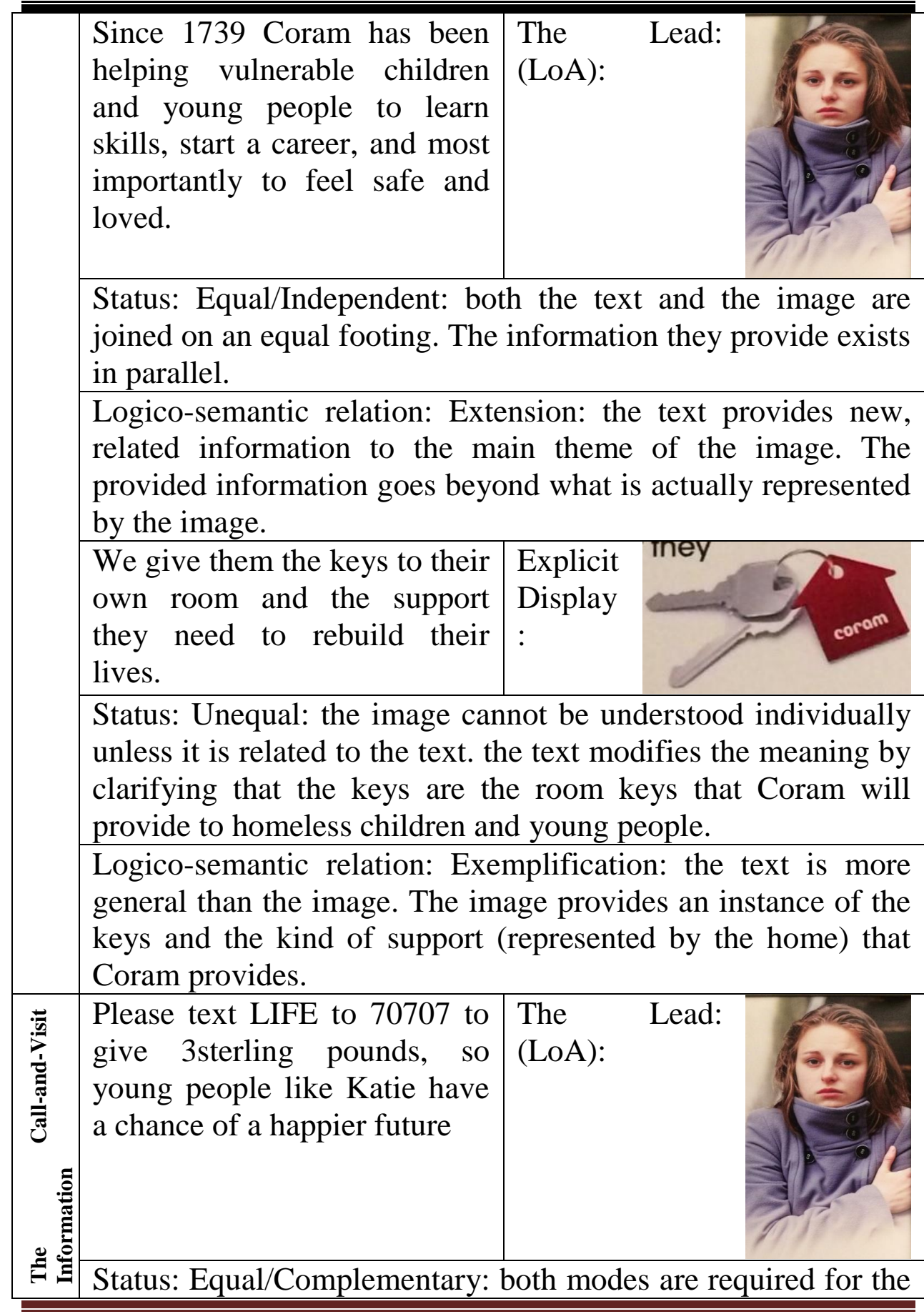

ELLS Vol.9 No.I (580) SPU December 2018 


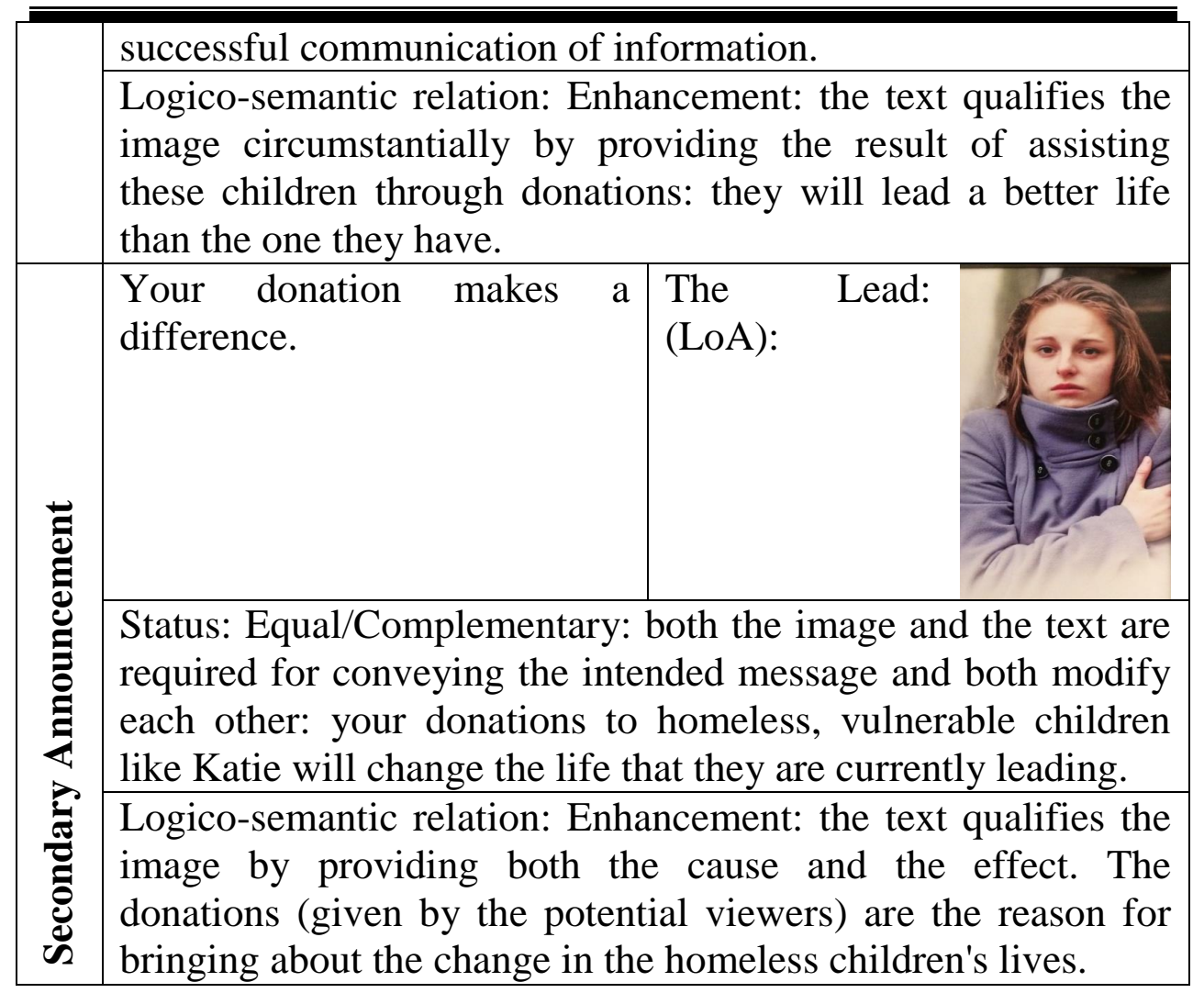

Table (6): Coram Legal Center: Status \& Logico-Semantic Relations

\section{7-5- Confederation of jīl al-tajīd: Non-commercial advertisement}

\section{7-5-1- Introductory}

The ad is an instance of charity advertising. It is about the donation to an association known as 'rābițat jīl al-tajdīd' (Confederation of Renovation Generation). The association provides the poor and the orphans with new clothes to celebrate the feast 'i $1 \mathrm{~d}$ '. Two modes are employed: the text and the imagery.

The advertisement components are arranged as follows: the Emblem is placed at the top left corner to capture the attention. It

\section{ELLS VoI.9 No.I (581) SPU December 2018}


Text-Image Relations in Print Advertisement: A Multimodal Discourse Analysis

shows the name of the provider of the service to add authenticity. It is verbally and visually realized.

The visual element consists of the Lead which, in turn, consists of the Locus of Attention (LoA). It shows the represented participant, a little girl, who dreams of and thinks about new clothes for the feast. The clothes items are the other represented participant in the image. The little girl is the reacter in a reactional process. She gazes in a dreamy way at the

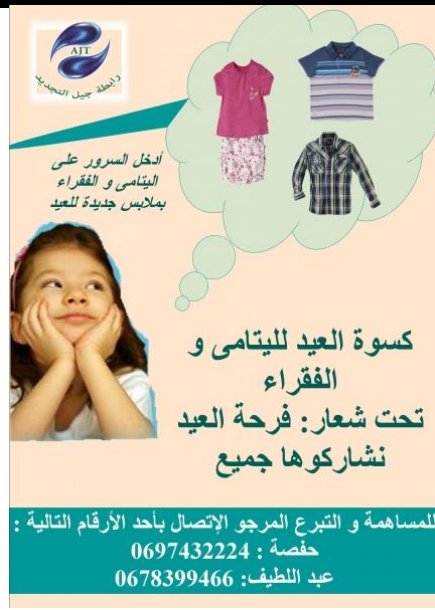
clothes, which constitute the phenomenon.

The girl's gaze is fixed on the clothes which are displayed in a thought bubble. The advertiser seeks to emphasize the little girl's longing for and 'jil al-tajdīd' Advertisement maximum interest in having new clothes.in this case, the viewer's role is that of an invisible onlooker. The girl is "the object of the viewer's...scrutiny." (Kress \& van Leeuwen, 2006, p.119). She is represented "as item(s) of information, object(s) of contemplation." (Ibid.).

Through its placing in the foreground of the image, it is the most salient and eye-catching element of the ad. Also, the placement of the thought bubble above the girl's level endows greater significance to the clothes.

As for the text, it consists of the Enhancer which is one statement that addresses the potential donors. It is written in a small font and is positioned at the top left corner below the Emblem. It specifies those who will receive the donation, namely, the orphans and the poor, and, similarly, clarifies the effect of donation. It forms an appeal for the audience to support the case: " أدخل السرور على اليتامى "و الفقراء بملابس جديدة للعيد 'adkil al-surūr 'alā al-yatamā wa al-fuqarā' bimalābis jadda lilīid' (Bring happiness to the orphans and the poor with new clothes for the feast).

ELLS VoI.9 No.I (582) SPU December 2018 
كسوة العيد لليتامى والفقراء تحت شعار : " Also, the textual component "فرحة العيد نشاركها الجميع 'kiswat al-îd lilyatāmā wa al-fuqarā' tḥ̂ta ši'ār: farhat al-1̄d nušarikuā al-jamī" (Feast clothes for the orphans and the poor are delivered under the slogan: the happiness of feast is shared by everyone) functions as the Primary Announcement of the advertisement. It is written in a big-sized font and is placed at the bottom of the right corner of the ad. The conveyed meaning is parallel to and clarifies the intended meaning of the LoA.

At the end of the ad is the Call-and-Visit information that provides essential information for contacting the service provider: اللمساهمة والتبر ع المرجو الإتصال بأحد الأرقام التالية: ..." 'lilmusāhama wa altabarru al-marjū al-ittiṣāl biaḥad al-arqām al-tāliya...' (For participation and donation, please contact: ...).

\section{7-5-2-Analysis:}

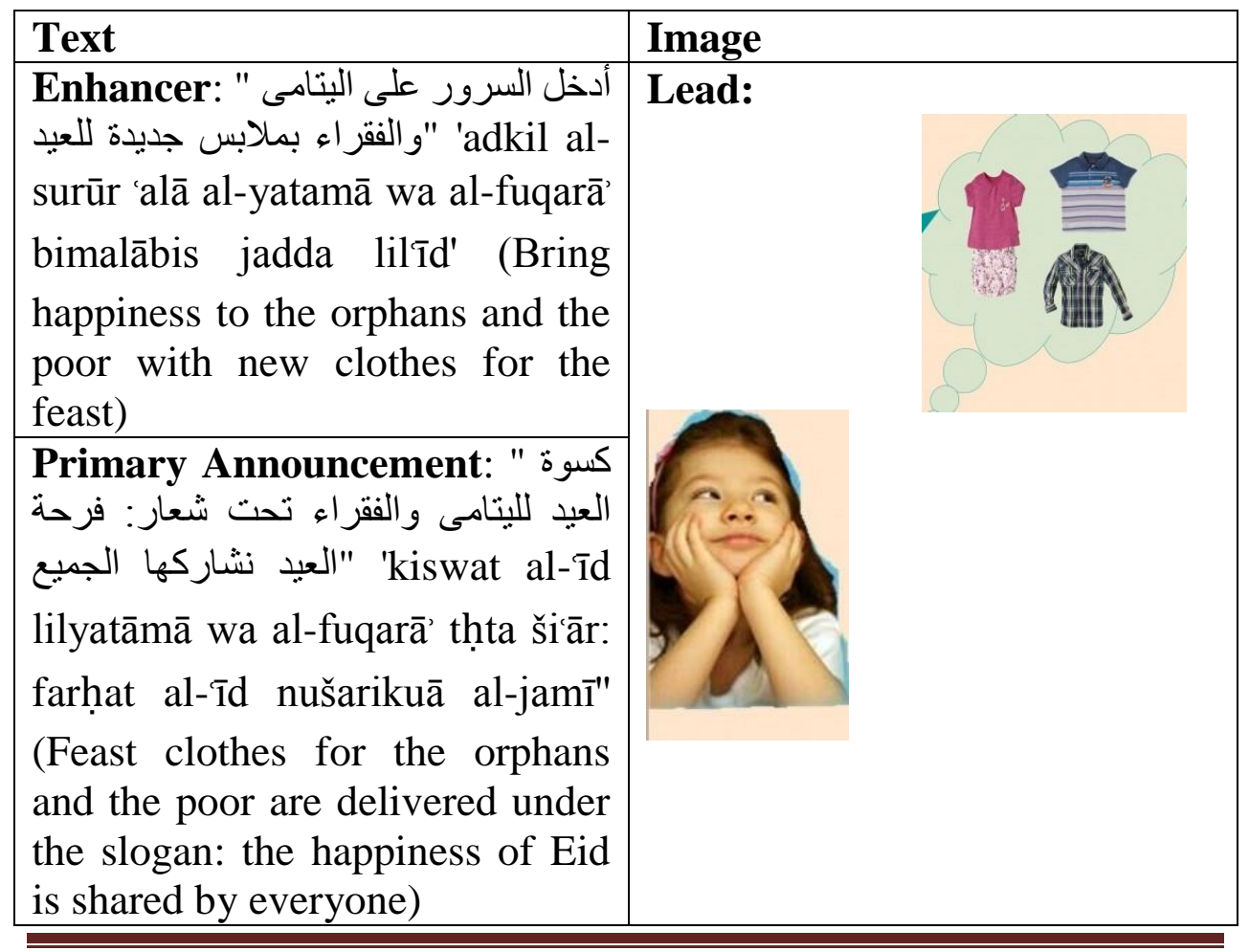

ELLS Vol.9 No.I (583) SPU December 2018 
Text-Image Relations in Print Advertisement: A Multimodal Discourse Analysis

Status:

1) Enhancer \& Lead: Equal-Complementary: the whole text is related to the whole image. If the Enhancer is read in isolation of the LoA, it will not achieve the same intended effect. The viewer makes a connection between the little girl's longing for new clothes and the happiness that could be brought to her. The text complements the meaning conveyed by LoA.

2) Primary Announcement \& Lead: Equal-Complementary: the two modes are required for the successful communication of meaning. Again, the text complements and clarifies the intended meaning of the Lead. It encapsulates what the advertiser wishes to communicate.

Logico-semantic relation:

1) Enhancer \& Lead: Exemplification: the text is more general than the image. The image exemplifies the text as it represents a classmember relationship. In other words, the image provides instances of such general elements mentioned in the text (e.g. the poor, the orphans, new clothes). The girl is an instance of the poor and the orphans and the clothes items are instances of clothes generally.

2) Primary Announcement \& Lead: Exemplification: the text is more general than the image and the image provides class members of the general concepts mentioned in the text.

Table (7): 'jīl al-tajdīd' Advertisement: Status \& Logicosemantic Relations

7-6- 'jamyat bait al-hair' (House of Goodness Society)

7-6-1-Introductory:

The advertisement is one of advertising campaign by the publishing house (Academia) and 'bait al-hair' society. The purpose of the advert is to encourage viewers to read and to help the needy at the same time. This can be achieved through

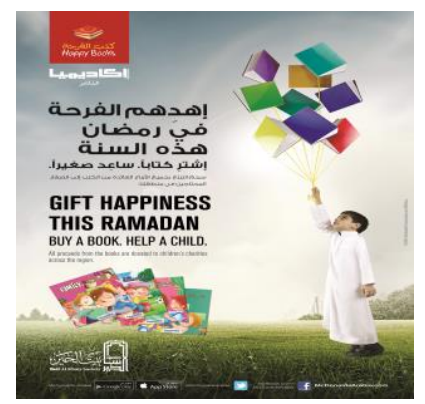

ELLS Vol.9 No.I (584) SPU December 2018 
purchasing a book and part of the book price will be used to help children in need in the region.

Both verbal and visual media are 'bait al-khair' Advertisement employed. The image consists of the

Lead which is divided into (LoA) and (Comp.LoA). The former is represented by a dynamic image of a little boy wearing 'Thoub' (traditional Arabic male wear) and holds a group of books. The boy is the actor in an action process: the boy is flying the books (goal) as balloons. Also, the boy is the reacter in a reactional process. He looks at the books flying in the air. The books constitute the phenomenon. The boy in the Thoub displays the little children, either those who will benefit from reading the books or from the donations.

The element of flying books is attention arresting. The books fly in the air as a group of balloons. They function as Explicit Congruent Display: the books are tangible in form and, likewise, symbolize the source of happiness for children. The advertiser's aim is to invite the viewer to demonstrate the link between the flying books and the little boy's happiness.

In addition, (LoA) shows the static image of a group of colorful children books that are demonstrated in a smaller size. They function as the Explicit Display. It is the photographic picture of a sample of the product provided by the publishing house and which will be bought.

The latter, (Comp. LoA) shows the background which is a vast field portrayed in a lighter hue to channel and focus the viewer's attention to an important aspect of (LoA), which is books. It refers to and complements the idea of happiness for children as they feel excited when playing in open clean areas.

To the left of the Lead is the text. The text starts with the Primary Announcement "إهدهم الفرحة قى رمضان هذه السنة 'ihdihhim alfarḥ̣a fi ramaḍān hādihī al-sana' (Gift happiness this Ramadan). It is marked by relative prominence in scale, color, font, and size. It

\section{ELLS Vol.9 No.I (585) SPU December 2018}


Text-Image Relations in Print Advertisement: A Multimodal Discourse Analysis

conveys the essence of the advertisement which is inviting the target audience to spread happiness during the holy month of Ramadan. However, it invites the viewers to think about the way to spread

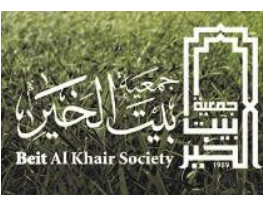
happiness. The viewer creates a link between the $3^{\text {rd }}$ person object pronoun "هم" 'hum' (them) and the (LoA) of the boy and the flying books.

The Primary Announcement is directly followed by the Enhancer. It is short in length as it consists of THREE statements.

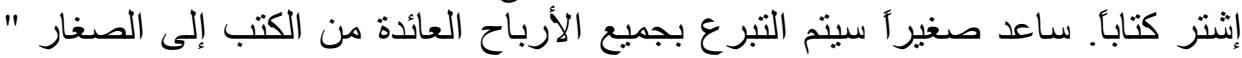
"ištarī kitāban, sāid șaḡīran. Sayatim al-tabrru' bigamī' al-arbāḥ al-ā̉ida min al-kutub ilā al-ṣiḡār al-muhtāgīn bimantiqatinā' (Buy a book. Help a child. All proceeds from the books are donated to children's charities across the region).

The Enhancer builds on and modifies the interaction between the Lead and the Primary Announcement. It provides further explanation of how to gift happiness and how to please little children. Besides, it contains interpersonal lexis such as 'buy', 'help' which carry attitudinal and affective thrust. Thus, the advertiser's message became clearer.

Other elements included in the advertisement are the Emblem, which is represented visually and verbally to refer to the logo of both the society and the publishing house. The Call-and-Visit element is also included to provide necessary information for contact. 
Yasmin M. El-Sayed

\section{7-6-2- Analysis:}

\begin{tabular}{|c|c|c|c|c|}
\hline \multirow{2}{*}{\multicolumn{2}{|c|}{$\begin{array}{l}\text { Text } \\
\text { Primary Announcement: } \\
\text { إهدهم الفرحة في رمضان هذه السنة } \\
\text { 'ihdihhim al-farha fi ramaḍan } \\
\text { hādihī al-sana' } \\
\text { (Gift happiness this Ramadan) }\end{array}$}} & \multicolumn{3}{|l|}{ Image } \\
\hline & & \multicolumn{3}{|l|}{ Lead: } \\
\hline \multicolumn{5}{|c|}{$\begin{array}{l}\text { Status: Unequal: the image can be interpreted individually. It can have } \\
\text { multiple meanings to the viewer. However, if the text is read in isolation } \\
\text { from the image, it will not be completely grasped. Similarly, the text is } \\
\text { realized by deixis to the image. The } 3^{\text {rd }} \text { person objective pronoun "هe } \\
\text { 'hum' (them) refers directly to the little boy in the Lead as a symbol of } \\
\text { needy children in general. Thus, the text is subordinate to the image. }\end{array}$} \\
\hline \multicolumn{5}{|c|}{$\begin{array}{l}\text { Logico-semantic relation: Exemplification: the text is more general than } \\
\text { the image. The } 3^{\text {rd }} \text { person objective pronoun refers to the needy children in } \\
\text { general. The image, on the other hand, provides an instance of the needy } \\
\text { children, which is the little boy. The term "لفرحة" 'al-farha' (happiness) is a } \\
\text { general term. However, it is represented in the image by a group of books } \\
\text { flying like balloons, which is a great source of joy for children. Thus, the } \\
\text { text and image reinforce each other by restating and reformulating the } \\
\text { meaning. }\end{array}$} \\
\hline \multirow{2}{*}{ 莺 } & \multicolumn{2}{|c|}{$\begin{array}{l}\text { إنثتر كتاباً. ساعد صغير'. } \\
\text { 'ištarī kitāban, sāid sagāiran' (Buy a } \\
\text { book. Help a child) }\end{array}$} & Lead: & $\underset{1}{\infty}$ \\
\hline & $\begin{array}{l}\text { Status: Equal/Complement } \\
\text { image and the text are req }\end{array}$ & $\begin{array}{l}\text { ary: the } \\
\text { uired for }\end{array}$ & & \\
\hline
\end{tabular}

\section{ELLS Vol.9 No.I (587) SPU December 2018}


Text-Image Relations in Print Advertisement: A Multimodal Discourse Analysis

conveying the intended meaning. They complement each other.

Logico-semantic relation: Exemplification: the text is more general than the image. The image provides instances of the two entities mentioned in the text, namely, "كتابأ" 'kitāban' (a book) and "صغير آ 'ṣagīiran' (a child).

Enhancement: the image enhances the meaning conveyed by the text through the circumstantial feature of cause/purpose. In other words, the text clearly identifies that the direct consequence of purchasing a book is assisting little children. The image helps represent this meaning.

سيتم التبرع بجميع الأرباح العائدة من الكتب إلى الى "الصغار المحتاجين بمنطقتنا لإنيا

'Sayatim al-tabrru' bigamī' al-arbāh al'àida min al-kutub ilā al-șiḡār almuhtāgīn bimantiqatinā'

(All proceeds from the books are donated to children's charities across the region)

Status: Unequal: the image is subordinate to the text. It is related to only a part of the text which is " الصغار al-ṣigāàr al-muhtāgīn bimanțiqatinā'

\section{ELLS Vol.9 No.I (588) SPU December 2018}


Logico-semantic relation: Extension: the text adds new information that is not clearly represented by the image. For instance, "the proceeds" of donation are not materially represented. Rather, the effects of donation are shown through the boy's happiness.

\section{Table (8): 'bait a-kair': Status \& Logico-semantic Relations}

\section{7-7-Sony Betamax: Commercia advertisement}

\section{7-7-1- Introductory:}

The advertisement is about a major advance in video equipment that was presented by Sony Corporation in the 1970s. Sony presented Betamax VCR, which was considered a revolutionary development in the field.

Two modes are employed: the text (the linguistic component) and the image (the visual component). The main target controlling the ad is that consumers in Arab countries like Gulf area (potential addressees) establish a link between authentic Arabic traditions and Sony conventions as a company that keeps the traditions of good manufacturing and good entertainment.

\section{$\begin{array}{llllll}\text { ELLS Vol.9 No.I } & \text { (589) SPU December } 2018\end{array}$}


Text-Image Relations in Print Advertisement: A Multimodal Discourse Analysis

At the top of the ad there is a centered phrase "سونى صاحبة التقاليد العريقة" Sonī șāhibat al-taqālīd al-'arīqa' (Sony the company with authentic traditions). This phrase is the Primary Announcement of the ad. It is written in the largest font size and in a different font face and placed outside the frame of the images. Directly below the Primary Announcement is the Secondary Announcement. It is the statement "وعالمنا العربي يقدر التقاليد "wa 'ālamunā al-'arabī yuqadir al-taqālī̄' (Likewise, our Arab world appreciates

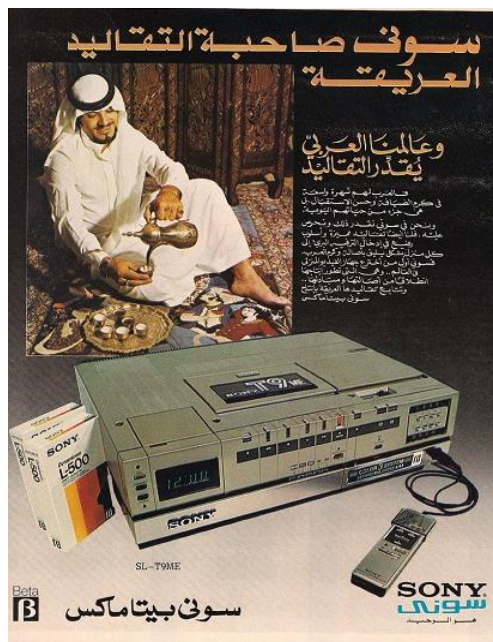
traditions). The advertiser is aware that

Sony Beta Max Advertisement Arabs appreciate their traditions and do not change them easily. The announcement directs the viewer's attention to the resemblance between Sony and the Arabs: both cherish traditions. It is a way to convince the viewer emotionally that there is a link or connection between Sony and the Arab world.

The following paragraph functions as the Enhancer. It extends the explanation of points of resemblance between Sony and the Arab world. The advertiser employs certain words to convey the message such as "كسن " "كرم الضيافة 'karam al-ḍiyafa' (hospitality), "الاستقبال 'husn al-istiqbāl' (willingness of reception) and so forth. The advertiser's employed technique is that the product is signified. In other words, the device has no meaning or value in itself unless it is attached with some entity that is valued and has a meaning to the addressee. In this case, Sony device is the signified and the authentic Arabic traditions are the signifier.

Moving to the visual component of the advert, it consists of the Lead which, in turn, consists of the Locus of Attention (LoA1). It shows an Arab man pouring Qahwa (Arabic coffee) from a coffee pot that is widely known in the Arab world as (Dallah). It is a

ELLS Vol.9 No.I (590) SPU December 2018 
dynamic naturalistic image where the man is the actor in an action process and the coffee is the goal. Also, he is the reacter in a reactional process as he smiles and looks at the poured coffee (phenomenon). The represented participants in the image, i.e. the man, the coffee pot and the cups, are the carrier in a symbolic attribute relation. They symbolize the Arabic traditions of generosity and hospitality. Presenting coffee is widely known in the Arab world and is a sign of the Arabic tradition of generosity and hospitality.

The image functions as an intermediary both for the abstractness of authentic traditions and for the device itself. The product has a value and meaning that is related to the Arab life-style. The Complementary to Locus of Attention (Comp.LoA) is the background of the image. It shows the floor on which the man sits, plate of Tamr (dates) which accompany Arabic coffee. The Comp.LoA assists in setting the atmosphere correlated with Arabic traditions.

The image of Sony VCR is (LoA2). It functions as Explicit Display of the product. It is presented close to the viewer through the close-up shot at a middle distance. It shows the object in full as if it is within the viewer's reach. This way facilitates the viewer's identification and contemplation of the advertised product. Both (LoA1) and (LoA2) are represented with approximately the same dimensions to imply that they are equal and co-exist. In other words, Sony VCR is part of Arabic traditions.

At the right of the advert is the Tag "سونى هو الوحيد" 'sonī huwa al-wahīd' (Sony is matchless). It is a one line statement in a small print. This line implies that Sony VCR is distinctive and unique. One possible meaning of this line can be that it is the only VCR that suits the Arab world as Sony appreciates traditions just like Arabs do. At the bottom left of the advert is the Emblem (both linguistic and visual). It shows the loge of the product for the viewer to identify and recognize.

\section{ELLS Vol.9 No.I (591) SPU December 2018}


Text-Image Relations in Print Advertisement: A Multimodal Discourse Analysis

\section{7-7-2- Analysis:}

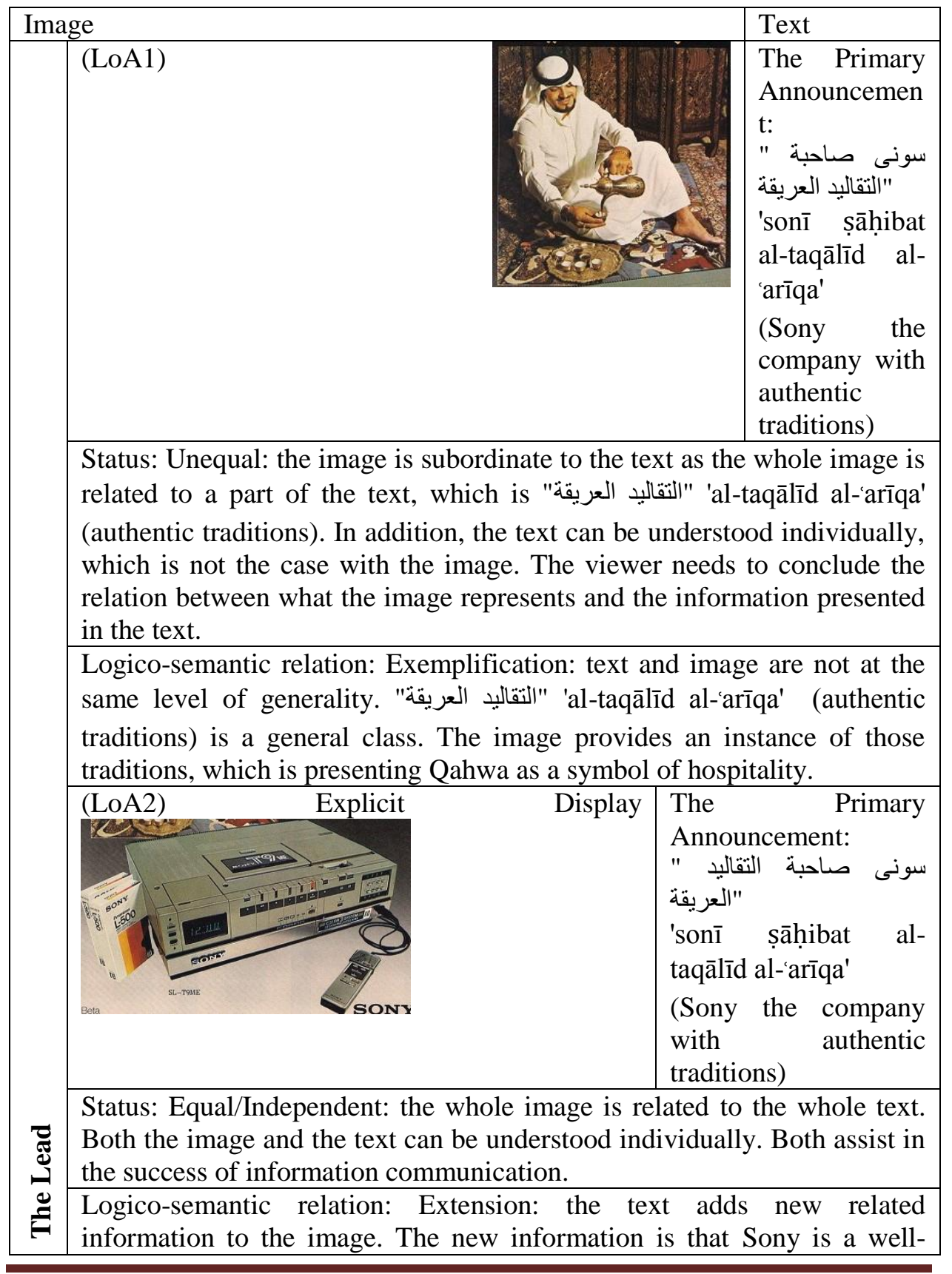

ELLS Vol.9 No.I (592) SPU December 2018 


\section{Yasmin M. EI-Sayed}

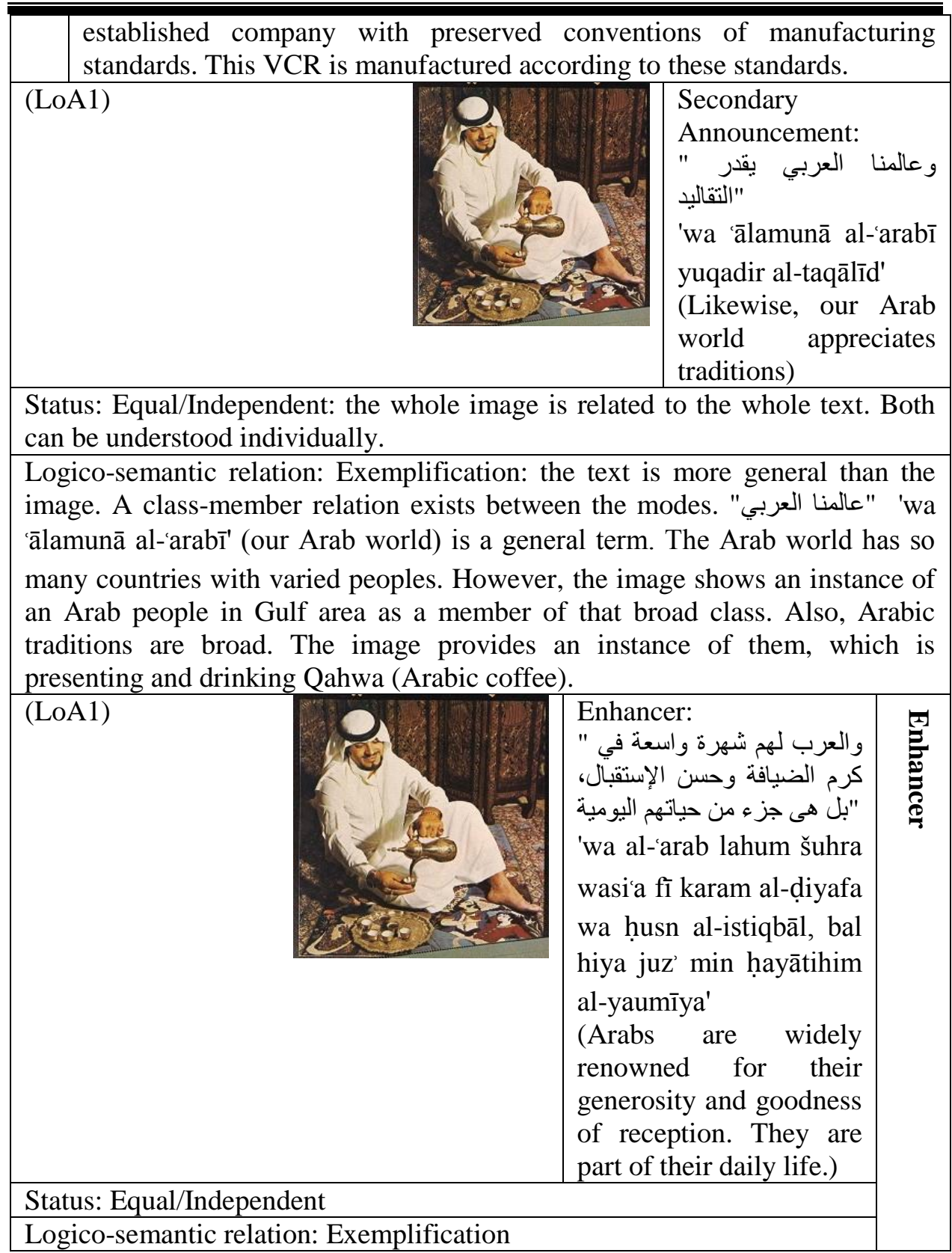

\section{ELLS Vol.9 No.I (593) SPU December 2018}


Text-Image Relations in Print Advertisement: A Multimodal Discourse Analysis

\begin{tabular}{|c|c|c|}
\hline $\begin{array}{l}\text { (LoA2): } \\
\text { Explicit } \\
\text { Display }\end{array}$ & Sens & 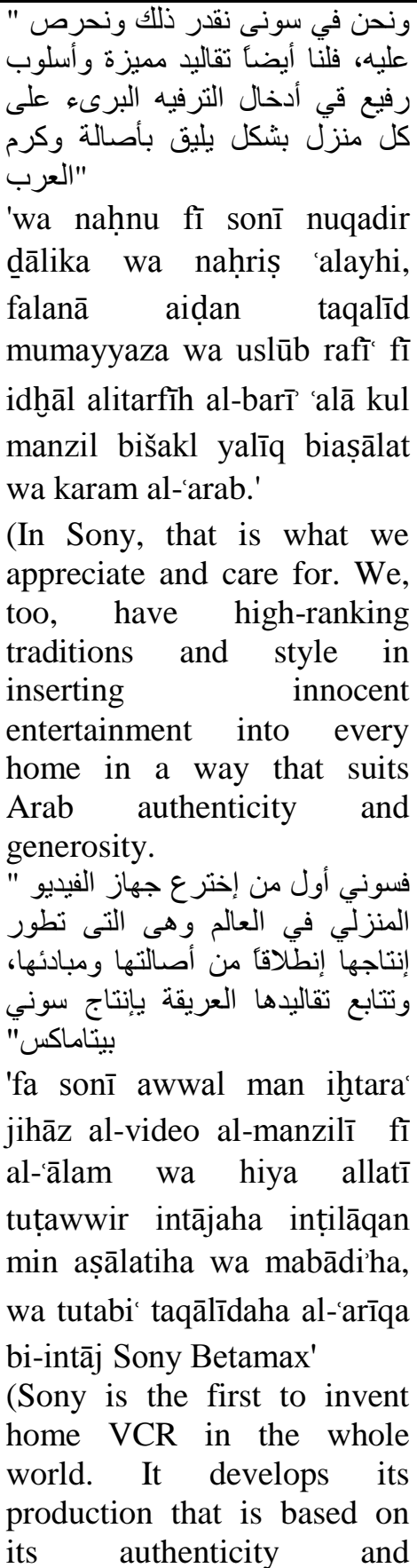 \\
\hline
\end{tabular}

\section{ELLS Vol.9 No.I (594) SPU December 2018}


Yasmin M. El-Sayed

\begin{tabular}{|l|l|}
\hline \hline & $\begin{array}{l}\text { principles. It continues to } \\
\text { follow these traditions } \\
\text { through the production of } \\
\text { Sony Betamax.) }\end{array}$ \\
\hline $\begin{array}{l}\text { Status: Equal/Complementary: the image and the text are joined equally and } \\
\text { modify one another. Both are employed to convey the advertiser's intended } \\
\text { meaning that Sony corporation preserves traditions of development, research } \\
\text { and successful partnership with its given consumers. }\end{array}$ \\
\hline $\begin{array}{l}\text { Logico-semantic relation: } \\
\text { Extension: the text extends the image by providing further ideational element. } \\
\text { Exemplification: the text is more general than the image. It discusses the } \\
\text { features of Sony (and its products) in general terms. However, the image } \\
\text { provides an instantiation of these products (Betamax VCR). This relation } \\
\text { entails that Betamax VCR suits the Arab world and its traditions. }\end{array}$ \\
\hline
\end{tabular}

Table (9): Sony Betamax: Status \& Logico-semantic Relations

\section{7-8- 'unūta' Perfume: Commercial advertisement}

\section{7-8-1- Introductory:}

The advertisement is about a feminine perfume called "أنوثة" 'unuta' (Femininity). It is manufactured by "قسمة والثبر اويشي" 'qisma wa al-šabrāwīšsi', a well-known Egyptian perfume company in the fifties. The addresser by the advert is mainly women. The advertiser's main goal is to persuade women to purchase the product. This is achieved through conveying the message that 'unutata' is as excellent as originally French perfumes and is essential complement of women's beauty.

\section{ELLS Vol.9 No.I (595) SPU December 2018}


The text and image are employed in the ad. The visual component consists of the Lead which consists of (LoA1) and (LoA2). (LoA1) shows the drawing of a beautiful elegant young woman sitting on a chair. The young lady is the reacter in a reactional process. The phenomenon is not clearly represented. However, what dominates the picture is the lady's gaze. She seems to be directly looking in the viewer's eyes. The viewer is invited to scrutinize her possessive attributes. The gaze establishes an imaginary link

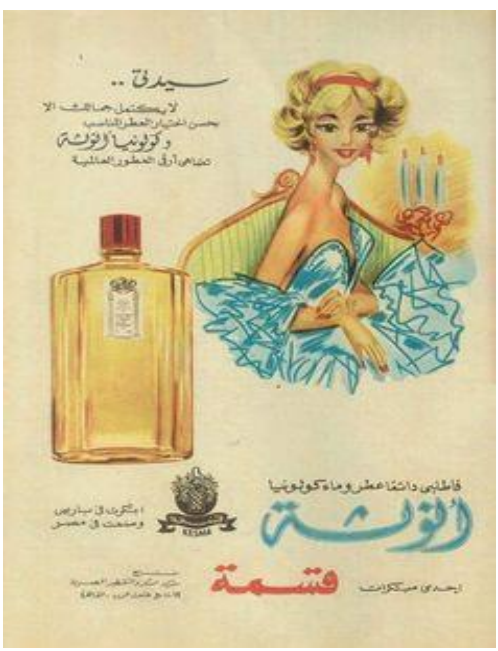
between the viewer and the represented participant. The woman's image demands the viewer's attention. (LoA2) shows the drawing of a perfume bottle that functions as the Explicit Display.

The linguistic component consists of the Enhancer: " لإيدتي... لا "usuta' Cologne Advertisement 'sayyidatī lā yaktamil jamālali illā bihusn ihtiyār al-iṭr al-munāsib' (Madam, your beauty is incomplete unless the perfume is correctly chosen). "وكولونيا أنوثه تضاهى أرقى العطور العالمية" 'wa koloniyā unūta tuḍāhī arqā al-'uṭūr al-'âlamīya' (Onoutha Cologne is as good as international perfumes). It consists of two statements that are directly addressed to women. They provide clarification of the reasons for choosing 'unūta' cologne: first, correct perfume is vital for woman's beauty and second, it is as good as other famous international perfume brands. The Enhancer functions as an introductory to the coming linguistic component, which is the Primary Announcement.

The Primary Announcement, "فأطلبى دائما عطر وماء كولونيا أنوثة ' 'fa uṭlubī dāiiman iṭ̂ wa mā' kolōniyā unūta' (Always ask for Onoutha perfume and eau de toilet), is the catchphrase and the attention arresting statement of the ad. It encapsulates the essence and

ELLS Vol.9 No.I (596) SPU December 2018 
intended message that women should buy 'unūta'. It is written in a bigger font than the Enhancer.

Another component of the ad is the tag: " أبتكرت في باريس وصنعت "في مصر 'ibtuirat fī pārīs wa șuni'at fī mișr' (innovated in Paris and manufactured in Egypt). Also, there is the Emblem (both linguistic and visual) which shows the logo and the slogan (the name) of the manufacturer:

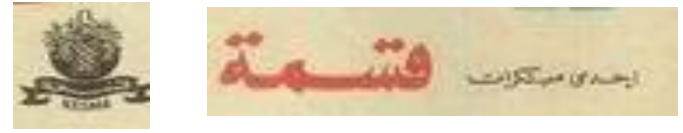

Visual and Linguistic Emblem

The final element of the advert is the Call-and-Visit Information. Its function is to provide the necessary contact information for the readers who are interested in the product.

\section{7-8-2- Analysis:}

\begin{tabular}{|c|c|c|}
\hline \multicolumn{2}{|c|}{ Text } & Image \\
\hline \multirow[b]{3}{*}{ 离 } & 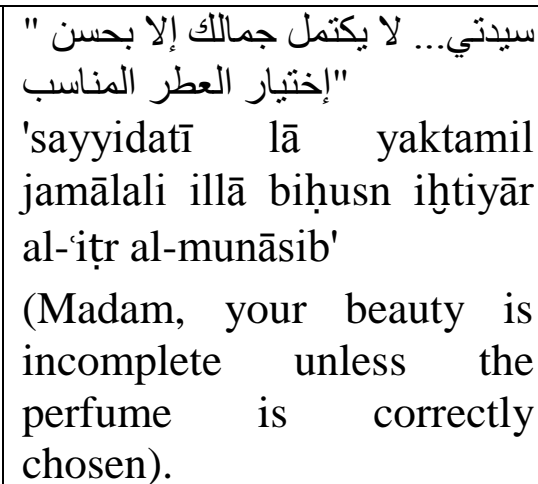 & - \\
\hline & \multicolumn{2}{|c|}{$\begin{array}{l}\text { Status: Unequal: the image is subordinate to the text as it } \\
\text { cannot be understood in isolation of the text. }\end{array}$} \\
\hline & \multicolumn{2}{|c|}{$\begin{array}{l}\text { Logico-semantic relation: Exemplification: the text is more } \\
\text { general than the image. The text is addressed to women who } \\
\text { care about their beauty generally. The image provides an } \\
\text { instance of such women. }\end{array}$} \\
\hline
\end{tabular}

\section{ELLS Vol.9 No.I (597) SPU December 2018}


Text-Image Relations in Print Advertisement: A Multimodal Discourse Analysis

\begin{tabular}{|c|c|}
\hline 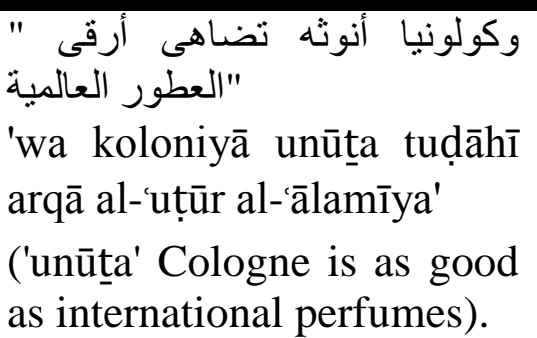 & $\begin{array}{ll}\text { (LoA2): } & \text { Explicit } \\
\text { Display } & \end{array}$ \\
\hline \multicolumn{2}{|c|}{$\begin{array}{l}\text { Status: Equal/Independent: the whole image is related to the } \\
\text { whole text. Both the image and the text can be understood } \\
\text { individually. }\end{array}$} \\
\hline $\begin{array}{l}\text { Logico-semantic relation: El } \\
\text { the cologne (the product). } \\
\text { describes the image through }\end{array}$ & $\begin{array}{l}\text { aboration: the image symbolizes } \\
\text { The text further specifies and } \\
\text { mentioning its quality of being as }\end{array}$ \\
\hline
\end{tabular}

The Primary Announcement: $\quad$ (LoA2): Explicit "فأطلبى دائمأ عطر وماء كولونيا أنوثة"

'fa uṭlubī dā'iman ițr wa mā'

kolōniyā unūta'

(Always ask for Onoutha perfume and eau de toilet)

Status: Equal/Independent: both the text and the image are joined on an equal footing.

Logico-semantic relation: Exposition: the text and the image reinforce each other by reformulating the meaning of " عطر وماء "كولونيا ' itr wa ma' koloniya' (Perfume and eau de toilet).

Table (10): 'Unuta' Perfume: Status \& Logico-semantic Relation

\section{8- Discussion \& Findings:}

The application of both the frameworks of Cheong's Generic Structure Potential (GSP) and Martinec \& Salway's system of textimage relations to the selected data, which consists of commercial and non-commercial ads, has outlined certain observations:

1) The textual and visual modes are present to achieve diverse functions including the following:

ELLS Vol.9 No.I (598) SPU December 2018 
a) Gain the viewer's attention: the Primary Announcement in each ad is the catchy element that incites the viewer. For example, 'Not what you had in mind for your first set فأطلبي ' of wheels, huh?' in the Candies Foundation ad or دائما عطر وماء كولونيا أنوثة 'fa uṭlubī dā'iman 'ițr wa mā' kolōniyā unūta' (Always ask for 'unūta' perfume and eau de toilet). In terms of the visual element, the image directs and arouses the viewer's interest towards the essence of the ad as in the 'Tareyton' cigarette ad. The image of the bruised female smoker aims to enforce the sense of loyalty to the brand.

b) Inform and stimulate action: both types of advertisements, commercial and non-commercial, present only related and necessary information for the viewer. Consequently, this information motivates the viewer to action. In the textual mode, this is performed basically by the Enhancer and its relation to the accompanying image. For instance, the Enhancer in the Coram Children's Legal Center consists of a short narrative that tells the story of the teenage girl featured in the ad (anecdote) to emotionally motivate the viewer's action. Similarly, the employed imagery is a persuasive mode. They are directly related and specific to the advertised product or service. They provide part of the intended meaning expressed in the textual mode. For instance, in the noncommercial ads, the represented participants provide Exemplification of the people who will benefit from the service. For example, the little Arab boy in the 'jīl altajdīd' ad provides an instance of the children who will benefit from the service. Likewise, the images in the commercial ads feature the products for the viewer to identify and recognize. Examples include Axle Grease shampoo.

\section{ELLS Vol.9 No.I (599) SPU December 2018}


Text-Image Relations in Print Advertisement: A Multimodal Discourse Analysis

2) Commercial advertisements are distinguished romcommercial advertisements as shown in the following table:

\begin{tabular}{|l|l|l|}
\hline Difference & Commercial ad & Non-commercial ad \\
\hline $\begin{array}{l}\text { What is being } \\
\text { advertised? }\end{array}$ & $\begin{array}{l}\text { Goods, services and } \\
\text { products }\end{array}$ & Behavior change \\
\hline $\begin{array}{l}\text { The aim of the } \\
\text { advertising process }\end{array}$ & Profit & $\begin{array}{l}\text { Contribution for } \\
\text { individual } \\
\text { society }\end{array}$ \\
\hline
\end{tabular}

Table (11): Commercial and Non-commercial Advertisements: Main Distinctive Points

These differences are clearly reflected in the textual and visual modes of the ads. "Axle Grease Shampoo", "Tareyton" Cigarette, 'unūta' Perfume, and Sony Betamax all feature an image of the product as the Locus of Attention (LoA) or the Explicit Display. The accompanying texts enhance the qualities of the product, as in the Enhancer or the Secondary Announcement. The advertiser's aim is to heighten the viewer's desire to purchase the product and, consequently, to achieve the profit. The kinds of logico-semantic relations holding between the two modes are Elaboration, Exposition, and Extension

Non-commercial advertisement, on the other hand, attempts to change the viewer's behavior through the emotional appeal employed in the modes. The images represent instances of the people mentioned in the text, for example, the teenage homeless girl in Coram foundation or the Arab little boy in 'bait a-hair' advertisement. The common type of logico-semantic relations holding between the modes is Exemplification and Enhancement.

3- The textual and visual modes employed in the ads are tied to the culture. Arabic advertisements, whether commercial or noncommercial, employ images and texts that directly address and cherish Arabic culture. For example, the Sony Betamax VCR ad features the image of a traditional Arab male in a traditional Arab

ELLS Vol.9 No.I (600) SPU December 2018 
atmosphere. The text, also, addresses the Arab people's interest and care for inherited traditions and customs of gracious hospitality and generosity.

English advertisements address issues related to their unique culture. For instance, the 'Tareyton' cigarette ad features a female smoker. The Candies Corporation advertisement employs the image text to address the issue of teenage pregnancy. The representation of the issue conforms to the norms of the western culture. Such ds emphasize the concepts of informality, independence, and individuality, which are deeply rooted in the culture.

It can be inferred that advertisers seek to achieve success in conveying the intended goals of their campaigns. Therefore, they establish an underlying relationship between their presentations and the culture of the target audience. The addressees will draw on their contextual and cutura knowledge to interpret the message.

\section{9- Conclusion:}

Advertisements form an entity that is carefully pre-planned and composed. The visual and linguistic elements of the advertisements support and complement each other to get across the intended idea to the viewer. Persuasion is the basic goal behind advertising as it "motivates people into action through influencing beliefs and desires" (O'Shaughnessy \& O'Shaughnessy, 2004, p. 25).

The present study is an attempt to investigate the text-image relations in advertisement as an instance of multimodal texts. Advertisements provide information through a variety of employed modes. The two modes, image and text, are regarded as material means through which meanings can be made. Therefore, they are analyzed in an integrated way where the parts are regarded as interacting and affecting one another. Advertisements usually have an overt form as well as covert content which remains invisible. However, the hidden meaning can be grasped through configuring the set of relations that hold between the components of the advertisement.

\section{ELLS Vol.9 No.I (601) SPU December 2018}


Text-Image Relations in Print Advertisement: A Multimodal Discourse Analysis

Two analytical approaches are applied to the study, namely, Martinec \& Salway's system of text-image relations and Cheong's Generic Structure Potential (GSP). It is demonstrated that imagery and text are integrated and interrelated and both serve the advertisers' overall intended meaning. Likewise, both facilitate orientation and processing of the advertisement. 


\section{References}

Alperstein, N. M. (2003). Advertising in everyday life. Cresskill, N.J.: Hampton Press.

Bakuuro, J. (2017). Demystifying Halliday's metafunctions of llanguage. International Journal of Language and Literature, 5(2), pp.211217.

Baldry, A. P. \& Thibault, P. J. (2006). Multimodal transcription and text analysis. London and Oakville: Equinox.

Barthes, R. (1967). Elements of semiology. London: Cape.

Barthes, R. (1977). Image, music, text. London: Fontana.

Barthes, R. (1983). The fashion system. Berkeley and Los Angeles: University of California Press.

Bateman, J. (2008). Multimodality and genre: A foundation for the systematic analysis of multimodal documents. Hampshire: Palgrave Macmillan.

Bavali, M. \& Sadighi, F. (2008). Chomsky's universal grammar and Halliday's systemic functional linguistics: An appraisal and a compromise. Pan-Pacific Association of Applied Linguistics (PAAL), 12 (1), pp.11-28.

Bogatyrev, P. (1971). The function of folk costume in Moravian Slovakia. The Hague: Mouton de Gruyter.

Cheong, Y. Y. (1999). Construing meaning in multi-semiotic texts: A systemic-linguistic perspective. Unpublished master thesis. National University of Singapore.

Cheong, Y. Y. (2004). The construal of ideational meaning in print advertisements. In K. L. O'Halloran (Ed.), Multimodal discourse analysis (pp. 163-195). London and New York: Continum.

Goddard, A. (1998). The language of advertising: Written texts. London: Routledge.

Jewitt, C. (2013). Multimodal methods for researching digital technologies. In S. Price, C. Jewitt, and B. Brown (Eds.), The SAGE handbook of digital technology research. Los Angeles: SAGE.

Kress, G. (2009). What is mode? In C. Jewitt (Ed.), The Routledge handbook of multimodal analysis (pp. 54-68). Abingdon: Routledge. 
Text-Image Relations in Print Advertisement: A Multimodal Discourse Analysis

Kress, G. (2012). Multimodal discourse analysis. In P. Gee \& M. Handford (Eds.), The Routledge handbook of discourse analysis (pp. 35-50). London and New York: Routledge.

Kress, G. and van Leeuwen, T. (2006). Reading images: A grammar of visual design ( $2^{\text {nd }}$ edition). London: Routledge.

Halliday, M. A. K. (1978). Language as social semiotic. London: Edward Arnold.

Lemke, J. (2012). Multimedia and discourse analysis. In P. J. Gee and M. Handford (Eds.), The Routledge handbook of discourse analysis (pp. 79-89). London: Routledge.

Martinec, R \& Salway, A. (2005). A system for image-text relations in new (and old) media. Visual Communication, 4(3), pp. 337-371.

Massaris, . (1997). Visual persuasion: The role of image in advertising.

Nugroho, A. D. (2009). The generic structure of print advertisement of Elizabeth Arden's INTERVENE: A multimodal discourse analysis. Kata, 11(1), pp. 70-84.

O'Halloran, K. L. (2011). Multimodal discourse analysis. In K. Hayland and B. paltridge (Eds.), Bloomsbury companion to discourse analysis (pp. 120-137). London: Bloomsbury.

O'Shaughnessy, J. \& O'Shaughnessy, N. J. (2004). Persuasion in advertising. London \& New York: Routledge.

Pittenger, R. E., Hockett, C. F., and Denehy, J. J. (1960). The first five minutes. Ithaca, NY: P. Martineau.

Salway, A. \& Martinec, R. (2002). Some ideas for modeling image-text combinations. CS-05-02, Department of Computing, School of Electronics and Physical sciences. London: University of Surrey.

Simoes, E. \& Freitas, L. (2012). Advertising and discourse nalysis. In J. P. Gee \& M. Handford (Eds.), The Routledge handbook of discourse analysis (pp. 427-440). London and New York: Routledge.

Stockl, H. (2009). Beyond depicting: Language-image links in the service of advertising. AAA-Arbeiten aus Anglistik und Amerikanistik, $34(1)$.

Thuy, T. (2017). Reading images: The grammar of visual design. VNU Journal of Foreign Studies, 33(6), pp.164-168.

\section{ELLS Vol.9 No.I (604) SPU December 2018}




\section{Yasmin M. El-Sayed}

van Leeuwen, T. (2015). Multimodality. In D. Tannen, H. E. Hamilton, and D. Schiffrin (Eds.), The handbook of discourse analysis. Oxford: John Wiley \& Sons, Inc.

Veltrusky, J. (1964). Man and object in the theatre. In P. L. Garvin (Ed.), A Prague school reader on esthetics, literary structure and style (pp. 83-91). Washington, D. C.: Georgetown University Press.

Williamson, J. (2002). Decoding advertising: Ideology and meaning in advertising. London: Marion Boyars.

Wu, S. (2014). A multimodal analysis of image-text relations in picture books. Theory and Practice in Language Studies, 4(7), pp. 14151420 . 